\title{
Unraveling the molecular targets pertinent to junction restructuring events during spermatogenesis using the Adjudin-induced germ cell depletion model
}

\author{
Weiliang Xia, Dolores D Mruk, Will M Lee ${ }^{\mathbf{1}}$ and C Yan Cheng \\ Center for Biomedical Research, Population Council, 1230 York Avenue, New York, New York 10021, USA \\ ${ }^{1}$ Department of Zoology, University of Hong Kong, Hong Kong, China \\ (Requests for offprints should be addressed to C Y Cheng; Email: y-cheng@popcbr.rockefeller.edu)
}

\begin{abstract}
During spermatogenesis, extensive restructuring takes place at the Sertoli-Sertoli and Sertoli-germ cell interface, which is regulated via intriguing interactions among cytokines, proteases, protease inhibitors, kinases, phosphatases, and transcription factors. This in turn determines the steady-state levels of integral membrane proteins at the cell junctions. We sought to further expand these observations using the Adjudin model. Adjudin is a potential male contraceptive that targets Sertoli-germ cell adhesion, causing exfoliation of spermatids and spermatocytes, but not spermatogonia, from the seminiferous epithelium. This model thus provides the means to identify crucial regulatory molecules and signaling pathways pertinent to junction restructuring events during spermatogenesis. In this study, genome-wide expression profiling of rat testes after treatment with Adjudin at the time of extensive junction restructuring was performed. Differentially regulated genes, such as cytokines, proteases,
\end{abstract}

protease inhibitors, cell junction-associated proteins, and transcription factors pertinent to junction restructuring were identified. These data were consistent with earlier findings; however, much new information was obtained which has been deposited at the Gene Expression Omnibus data repository website: http://www.ncbi.nih.gov/geo/ with Accession number: GSE5131. The primary signaling events pertinent to junction restructuring in the testis induced by Adjudin were also delineated using bioinformatics. These findings were also consistent with recently published reports. The identified molecular signatures or targets pertinent to junction dynamics in the testis as reported herein, many of which have not been investigated, thus offer a framework upon which the regulation of junction restructuring events at the Sertoli-Sertoli and Sertoli-germ cell interface pertinent to spermatogenesis can be further studied.

Journal of Endocrinology (2007) 192, 563-583

\section{Introduction}

In adult rat testes, spermatogonia (diploid, 2n) divide and differentiate into spermatids (haploid, 1n) while traversing the seminiferous epithelium from the basal to the apical compartment, reaching the luminal edge of the seminiferous epithelium to permit spermiation that occurs at stage VIII of the epithelial cycle. For spermatogonia to become fully developed elongate spermatids (i.e. spermatozoa) takes $\sim 58$ days in rats and spans $\sim 4.5$ rounds of the seminiferous epithelial cycle ( $\sim 12-14$ days per cycle in rats) with each cycle comprising 14 distinct stages that display unique association between Sertoli and germ cells at different developmental stages (Parvinen 1982, de Kretser \& Kerr 1994). Thus, extensive restructuring at the Sertoli-Sertoli and Sertoli-germ cell interface is taking place in the seminiferous epithelium during spermatogenesis (Cheng \& Mruk 2002, Mruk \& Cheng 2004b). Since different germ cells are arranged into layers across the epithelium and progressively migrate toward the seminiferous tubule lumen, their interactions with Sertoli cells also differ spatially (Russell 1977). It is well established that spermatogenesis is regulated by follicle-stimulating hormone (FSH) and testosterone under the influence of the hypothalamicpituitary-testicular axis (de Kretser \& Kerr 1994, Eddy 1998). However, crosstalk between Sertoli and germ cells in the seminiferous epithelium and their regulation pertinent to spermatogenesis and spermiogenesis remain largely unexplored. Recent studies have shown that the intriguing events of Sertoli-germ cell interactions at the cell-cell interface are regulated by cytokines (e.g. transforming growth factor (TGF)- $\beta 3$ and tumour necrosis factor (TNF) $\alpha$ ) that work in concert with proteases, protease inhibitors, kinases, and phosphatases in the microenvironment of the seminiferous epithelium behind the basement membrane. The collective interactions of these molecules determine the timely 'opening' and 'closing' of the blood-testis barrier (BTB) to facilitate preleptotene spermatocyte migration across the 
barrier and germ cell movement during the epithelial cycle (Mruk \& Cheng 2004b). Additionally, supporting evidence for this local regulatory mechanism is derived from germ cell transplantation studies showing that rat spermatogonia injected into seminiferous tubules in mice differentiate independent of the surrounding milieu (for reviews, see McLean et al. 2001 and Matzuk 2004).

Adjudin [1-(2,4-dichlorobenzyl)-1H-indazole-3-carbohydrazide], formerly known as AF-2364, is a molecule that mediates adherens junction disruption at the Sertoli-germ cell interface (Mruk \& Cheng 2004b). It is a derivative of lonidamine having a more potent aspermatogenic activity but less toxicity versus lonidamine (Cheng et al. 2001, Grima et al. 2001). When administered to adult rats by gavage, Adjudin exerts its effects primarily at the Sertoli-germ cell interface, causing germ cell sloughing, in particular elongating/elongate/round spermatids and spermatocytes from the epithelium without perturbing adhesion between spermatogonia and Sertoli cells; as such, its effects are reversible (Mruk \& Cheng 2004b, Cheng et al. 2005). Based on these initial observations, Adjudin has been used to develop an in vivo model to characterize cell-cell interactions and junction dynamics pertinent to spermatogenesis (Siu et al. 2003b, 2005, Lee \& Cheng 2005, Xia \& Cheng 2005, Yan \& Cheng 2005, Xia et al. 2006). For instance, the integrin/focal adhesion kinase (FAK)/phosphatidylinositol 3-kinase (PI-3) kinase/extracellular signal regulated kinase (ERK) signaling pathway was shown to regulate Sertoligerm cell adherens junction (AJ) dynamics, particularly the apical ectoplasmic specialization (ES), using Adjudin-treated rat testes (Siu et al. 2003b, 2005). Furthermore, a loss of protein-protein interactions between integral membrane proteins and their adaptors at the $\mathrm{AJ}$ (e.g. apical and basal ES) to facilitate AJ and BTB restructuring were also detected using this model (Lee et al. 2005, Xia \& Cheng 2005). This signal pathway activation and the loss of protein-adaptor interactions at the $\mathrm{AJ}$ were also demonstrated during spermatid loss from the epithelium, which was induced by suppressing intratesticular androgen level using testosterone and estrogen implants in adult rats (Wong et al. 2005, Xia et al. 2005b, Zhang et al. 2005). Collectively, these data clearly illustrate that the Adjudin model is a valuable tool to identify signaling pathways pertinent to AJ dynamics and possibly the regulatory mechanisms pertinent to spermatogenesis. Since DNA microarray technique has been widely used to unravel global transcriptional changes (for a review, see Stoughton 2005), we sought to identify these potential regulators of junction remodeling pertinent to spermatogenesis using expression microarray. In this report, we describe findings based on the use of Affymetrix Genechips (rat genome) that contain $\sim 30000$ probe sets to characterize the expression profile in rat testes following treatment with Adjudin at the time of AJ restructuring. The genes and the signaling conduits identified by microarray could provide a framework to further probe the biological processes of junction restructuring pertinent to spermatogenesis.

\section{Materials and Methods}

\section{Animals and microarray gene chips}

Male Sprague-Dawley rats $(\sim 300 \mathrm{~g}$ b.w.) were purchased from Charles River Laboratories (Kingston, MA, USA). The use of animals in this study was approved by The Rockefeller University Animal Care and Use Committee, with protocol numbers 03017 and 06018 . Rats were treated with a single dose of Adjudin at time 0 by gavage at $50 \mathrm{mg} / \mathrm{kg}$ body weight (b.w.) as described earlier (Cheng et al. 2001, Grima et al. 2001). For microarray analysis, rats $(n=3$ for time 0 and $96 \mathrm{~h}$; $n=2$ for $8 \mathrm{~h}$ ) were killed by $\mathrm{CO}_{2}$ asphyxiation. These two time points were selected since by $8 \mathrm{~h}$, even though some elongate and elongating spermatids had begun to exfoliate from the seminiferous epithelium, most germ cells remained attached to Sertoli cells in the seminiferous epithelium. Even for those that were detached from the epithelium, they were still found in the tubule lumen. As such, this is the time that extensive AJ restructuring was occurring at the Sertoli-germ cell interface, but germ cells remained in the samples being analyzed by microarray. By day 4, virtually all elongating/ elongate spermatids were depleted from the epithelium and most round spermatids and spermatocytes had left the epithelium and tubule lumen as well, suggesting the induced AJ restructuring had subsided as shown in earlier studies (Chen et al. 2003, Mruk \& Cheng 2004a,b). Testes were frozen immediately in liquid nitrogen upon termination and stored at $-80^{\circ} \mathrm{C}$ until use for RNA extraction. Rat Genome 2302.0 GeneChips were purchased from Affymetrix, Inc. (Santa Clara, CA, USA) and used for this study.

\section{Total RNA preparation}

About $0 \cdot 1 \mathrm{~g}$ testis from each sample was used for total RNA isolation using TRIZOL (Invitrogen). RNA was then purified with an RNeasy cleanup kit (Qiagen). Total RNA quality was assessed with an Agilent 2100 Bioanalyzer (Agilent Technologies, Palo Alto, CA, USA).

\section{cRNA labeling, hybridization, and array scanning}

cDNA synthesis and cRNA labeling by in vitro transcription (IVT) were performed using GeneChip One-Cycle Target Labeling and Control Reagents (Affymetrix, P/N 900493). Briefly, total RNA $(\sim 5 \mu \mathrm{g})$ prepared as mentioned above was first reverse transcribed using a T7-oligo (dT) promoter primer in the first-strand cDNA synthesis reaction. Following RNase $\mathrm{H}$-mediated second-strand cDNA synthesis, the double-stranded cDNA was purified and served as a template in the subsequent in vitro transcription reaction. The IVT reaction was carried out in the presence of T7 RNA polymerase and a biotinylated nucleotide analog/ribonucleotide mix for cRNA amplification and biotinylation following the protocols provided by the manufacturer. The biotinylated cRNA targets were then 
purified using RNeasy spin columns, and fragmented at $94{ }^{\circ} \mathrm{C}$ for $35 \mathrm{~min}$ in a fragmentation buffer $(40 \mathrm{mM}$ Trisacetate $(\mathrm{pH} 8 \cdot 1)$ containing $100 \mathrm{mM}$ potassium acetate and $30 \mathrm{mM}$ magnesium acetate), which were used for hybridization with GeneChips. The integrity of the labeled cRNA was again assessed by Agilent 2100 Bioanalyzer before hybridization. The GeneChip Fluidics Station 450 was used for array hybridization and processing and the Affymetrix GeneChip Scanner 3000 for array scanning. cRNA labeling, hybridization, and array scanning were performed at The Rockefeller University Genomics Resource Center (New york, NY, USA). The experiment was repeated twice using different samples.

\section{Microarray data analysis}

Scanned images of the microarray were first visually examined to rule out physical anomalies or excessive high background. Data were initially accessed using the Microarray Suite 5.0 (MAS) software (Affymetrix) and all probe sets on each array were scaled to a target signal intensity of 250 . This prescaling assured data uniformity in subsequent cross-chip comparison. MAS assessment also reported the background noise, the number of probe sets that are present, marginal, or absent in the samples out of a total of 31099 probe sets on Rat Genome 230 2.0 GeneChip based on signals. Data were then exported and analyzed using the GeneSpring software (Version 7.2, Agilent). All samples were grouped accordingly into time 0 (control), 8-h and 4-day post-Adjudin treatment. Data were normalized in three steps: step 1 , data transformation to set measurements from $<0.01$ to 0.01 . Step 2, per chip normalization to the median or 50th percentile intensity of the probe set in each chip to remove non-biological variations such as differences in the experiment conditions. Step 3, per gene normalization to normalize all samples to time 0 (the median value for each probe set among the three control samples was used). Data were further filtered using the filtering on flags feature (namely signal detection, present, marginal or absent; at least present or marginal in one of the sample after Adjudin treatment) in Genespring to identify genes that are expressed in one of the experimental conditions under study (e.g. Adjudin treatment) and expression raw value (at least 50) to remove unreliable genes. Thereafter, genes that were expressed differentially and were statistically significantly different from control (normal rat testes, $P<$ $0 \cdot 05)$ were determined by one-way ANOVA for multiple comparisons between samples in control $(n=3)$ and treatment groups $(n=2$ for $8 \mathrm{~h}$ or $n=3$ for 4-day post-Adjudin treatment) with multiple test correction (default option) and multiple test correction set to 'none', using the Agilent GeneSpring software. Genes with significant changes in their steady-state mRNA levels in comparison with control were scored and grouped. Hierarchical clustering analysis (unsupervised) was performed in the GeneSpring software using default settings. Gene ontology and signaling pathway analysis was performed using Onto Express and Pathway Express programs available from Wayne State University (Draghici et al. 2003a,b, Khatri et al. 2004, 2005). The Affymetrix probe set ID corresponding to the specific gene at the GeneBank database with fold changes in the steady state mRNA levels at $8 \mathrm{~h}$ or at day 4 were imported into the programs and the top-ranking pathways were identified.

\section{Quantitative real-time RT-PCR and data analysis}

To validate relative expression levels of selected genes from microarray studies, quantitative real-time RT-PCR (qPCR) was performed using an Applied Biosystems Prism 7700 Sequence Detection System with SYBR Green PCR Master Mix (Applied Biosystems, Inc., Foster City, CA, USA). Primers for qPCR were designed using either the Oligonucleotide Properties Calculator at www.basic.northwestern.edu/biotools/oligocalc. html or the Primer Express (Version 2.0) from Applied Biosystems, Inc. and were compared with the existing database at GenBank using the basic local alignment search tool (BLAST) to ensure specificity (see Table 1). Briefly, total RNA from different samples were prepared using TRIZOL (Invitrogen) and treated with DNaseI (Invitrogen) to remove contaminating genomic DNA before reverse transcription. Equal amount of total RNA was then reverse transcribed using Moloney murine leukemia virus reverse transcriptase (M-MLV RT, Promega) with $2 \mu \mathrm{g}$ RNA in a $25 \mu \mathrm{l}$ reaction. Both primers ( 5 pmol each)

Table 1 Gene-specific primers for real-time RT-PCR

\begin{tabular}{|c|c|c|c|c|}
\hline \multirow[b]{2}{*}{ Target gen } & $\begin{array}{l}\text { Genbank accession } \\
\text { number }\end{array}$ & Forward primer (sense, $5^{\prime}-3^{\prime}$ ) & Reverse primer (antisense, $5^{\prime}-3^{\prime}$ ) & Product length $(b p)$ \\
\hline & & & & \\
\hline$c-f \circ s$ & X067̄69 & 5'-TTCTCAATGACССТGAGCCСА & 5'-TGCCGGAAACAAGAAGTCATC & 101 \\
\hline Cxc/10 & ВC058444 & 5'-TCССТGTTTCTССТGАССАTG & 5'-AGCCTTGCTGCTGGAGTTACT & 101 \\
\hline$I L-1 \alpha$ & NM_017019 & 5'-TTCCTCGTCCTAAGTCACTCGC & 5'-TGGTTCCACTAGGCTTTGCTCT & 101 \\
\hline Jun & NM_021835 & 5'-CСТTGAAAGCGCAAAACTCC & 5'-CCCACTGTTAACGTGGTTCATG & 101 \\
\hline Stat3 & NM_012747 & 5'-TCCССССGСАСТTTAGATTCA & 5'-TCCATGTCAAACGTGAGCGAC & 101 \\
\hline Tnfrsfla & NM_013091 & 5'-TGCCACGCAGGATTCTTTCT & 5'-TTTGCAACTGGAGGTAGGCAC & 101 \\
\hline
\end{tabular}


and various templates (serially diluted control testis cDNA for generating the standard curve, and $1 \mu \mathrm{l}$ Reverse transcription product from all samples) were mixed with $2 \times$ SYBR Green PCR Master Mix in a $25 \mu \mathrm{l}$ final reaction volume. The thermal cycler conditions were $10 \mathrm{~min}$ at $95^{\circ} \mathrm{C}$, followed by two-step $\left(15 \mathrm{~s}\right.$ at $95^{\circ} \mathrm{C}$ and $1 \mathrm{~min}$ at $60^{\circ} \mathrm{C}$ ) PCR for 40 cycles, and a slow heating up to $95^{\circ} \mathrm{C}$ for dissociation analysis at the end to ensure the purity of the PCR product. Amplification data were analyzed with an Applied Biosystems Prism Sequence Detection Software (Version 2.1). The cycle threshold $\left(C_{\mathrm{T}}\right)$ value corresponding to the PCR cycle number at which fluorescence emission in real time reached a threshold above the baseline emission was determined. The $C_{\mathrm{T}}$ value for each sample was then exported and analyzed in Microsoft Excel. A combination of standard curve and comparative $C_{\mathrm{T}}$ methods were applied for the analysis (User Bulletin \#2 ABI PRISM 7700 Sequence Detection System, Applied Biosystems). For standard curve method, $C_{\mathrm{T}}$ for Stat 3 and S-16 were plotted as $C_{\mathrm{T}}$ value against logarithm of relative input RNA amount respectively, and then the input RNA amount for each sample was calculated based on its $C_{\mathrm{T}}$ value in reference to the corresponding standard curve. Relative expression of Stat 3 was normalized to the S-16 control for each sample. For comparative $C_{\mathrm{T}}$ method, the difference of $C_{\mathrm{T}}$ between the target gene and S-16 for each sample was calculated $\left(\Delta C_{\mathrm{T}}\right)$ and then this difference for other samples was compared with that of a particular sample $\left(\Delta \Delta C_{\mathrm{T}}\right)$. The expression level in any sample relative to that particular sample was given by $2^{-\Delta \Delta C T}$. All reactions were prepared in triplicate and three independent sets of samples were used in each experiment. Results of qPCR were analyzed by one-way ANOVA for multiple comparisons using the JMP IN statistical analysis software package (Version 4, SAS, Inc., Cary, NC, USA).

\section{Immunohistochemistry and immunoblot analysis}

Immunohistochemistry (IHC) for selected genes was performed essentially as previously described (Xia \& Cheng 2005). Antibodies used in this study were either raised in this laboratory (rabbit anti-testin (Cheng \& Bardin 1987), anticathepsin L (Lee et al. 1986), $\alpha_{2}-\mathrm{MG}$ (Cheng et al. 1990)) or purchased from Zymed-Invitrogen (Carlsbad, CA, USA) (rabbit anti-claudin 3 polyclonal antibody). Immunoblot analysis was performed as described earlier (Xia \& Cheng 2005). Testis lysates from samples were prepared and resolved by SDS-PAGE and probed against a panel of antibodies.

Assessing changes in the steady-state $m R N A$ levels of target genes in testes taking into account cellular composition alteration in the seminiferous epithelium following Adjudin treatment - a mathematical model

Adjudin treatment induces massive germ cell depletion from the seminiferous epithelium, with initial loss of elongating/elongate spermatids, to be followed by round spermatids and spermatocytes (Chen et al. 2003; Fig. 1A-C). As such, the cellular composition in the epithelium changes with time following treatment, particularly between days 1 and 4, during germ cell sloughing. For instance, if a protein is exclusively expressed by Sertoli cells, such as occludin, its induction that was detected by RT-PCR and/or immunoblotting following Adjudin treatment versus controls by day 4 may simply reflect an increase in cellular RNAs or proteins contributed by Sertoli cells in the samples being analyzed because of declining germ cell numbers as a result of germ cell loss. This thus makes it difficult to assess if induction of a target protein is in fact related to junction restructuring or the result of cellular composition alteration. Herein, we provide a mathematical model to relate changes in cellular composition and an alteration of expression level of a target protein/gene so as to provide a threshold by which one can accept or reject data generated in this Adjudin or similar animal models. Because non-germ cell types in the testis (e.g. Sertoli, Leydig, and myoid cells) do not have any significant changes after Adjudin treatment (Cheng et al. 2001, 2005, Grima et al. 2001), we collectively assigned these cell types as somatic cells and categorized them under the Sertoli cell item as an entity. We also did not discriminate germ cells at different

Figure 1 Morphological analysis of testes after Adjudin treatment and a summary of the gene expression profiles in testes at the time of extensive junction restructuring at the Sertoli-germ cell interface. $(\mathrm{A} ; \mathrm{a}-\mathrm{C})$. Paraffin sections of testes stained with hematoxylin in normal (Ctrl) rats (a) versus $8 \mathrm{~h}$ (b) and day 4 (c) after Adjudin treatment, spermatids were still loosely attached to Sertoli cells in the seminiferous epithelium by $8 \mathrm{~h}$ (b) post-treatment even though elongating spermatids and spermatocytes were found in lumen of most tubules examined versus day 4 (c), when virtually all spermatids were depleted from the epithelium , and control (Ctrl, normal) testes. Bar in a $=40 \mu \mathrm{m}$ which applies to (b and c); bar in inset in $\mathrm{a}=150 \mu \mathrm{m}$, which applies to insets in (b and c). (d) Changes in testis weight (per organ pair) after Adjudin treatment as a result of germ cell loss $(n=5)$. Percentage of testis weight in comparison with control (Ctrl, normal rats) testes was also annotated. ns, Not significantly different from control (normal) rats by ANOVA; ${ }^{*} P<0 \cdot 01$. (e) Each of the total of 31099 probe sets on the Affymetrix GeneChip Rat Genome 2302.0 array, was assigned a Flag to indicate its presence $(\mathrm{P})$, marginal $(\mathrm{M})$, or absence $(\mathrm{A})$ based on the signal detected. The solid bar summarized the mean percentage of genes in each of the three groups from a total of eight samples $(n=3$ for control testes, $n=2$ for $8 \mathrm{~h}$ and $n=3$ for 4 days after Adjudin treatment). All the raw microarray data have been deposited at the Gene Expression Omnibus (GEO) data repository website: http://www.ncbi.nih.gov/geo/ with the accession number: GSE5131. ( $\mathrm{f}$ and g) Normalized expression level of each gene at $8 \mathrm{~h}$ or at day 4 was plotted against its raw expression level (signal intensity) in control (Ctrl) testes. Each dot is a mean of data from two $(8 \mathrm{~h})$ or three (Ctrl and day 4) gene chips using different samples for hybridization. The two green lines above and below the green line marked at 1 represent a twofold change, namely induction or suppression, in gene expression level versus control. The color scheme (red signifies an increased expression and blue decreased expression) shown herein is the same as in Fig. 4A. (B) Venn diagram summarizing the number of genes with at least twofold changes in expression levels at $8 \mathrm{~h}$ and at day 4 from a total of 1466 transcripts that were found to be differentially regulated by one-way ANOVA. 
A

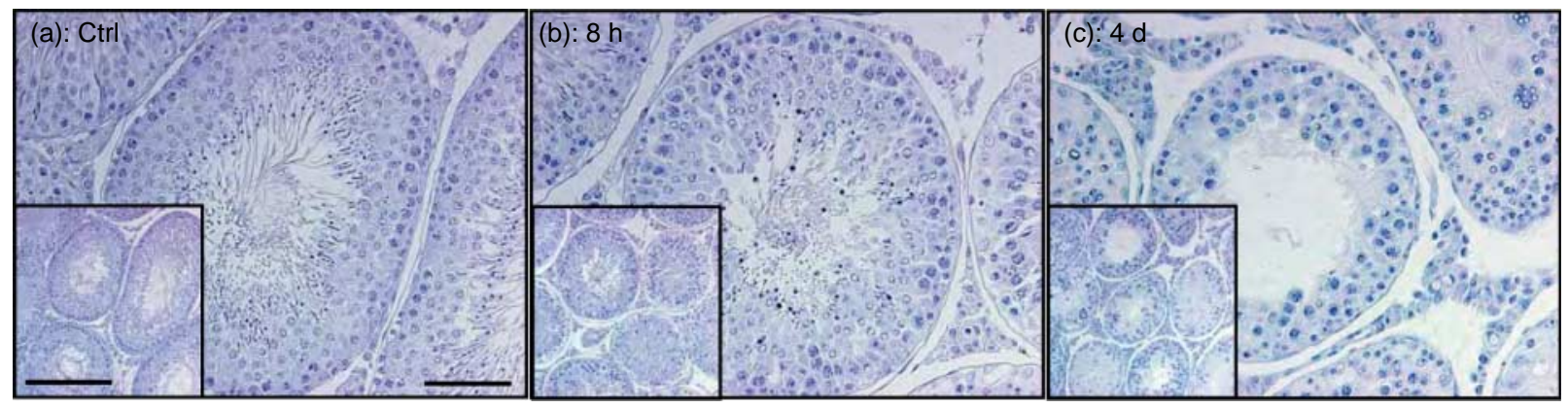

(d)
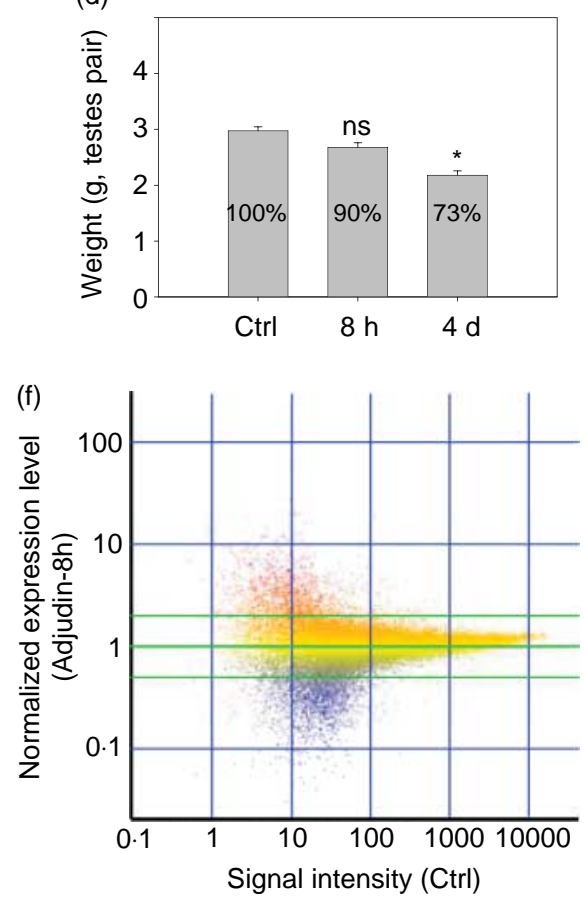

(e)

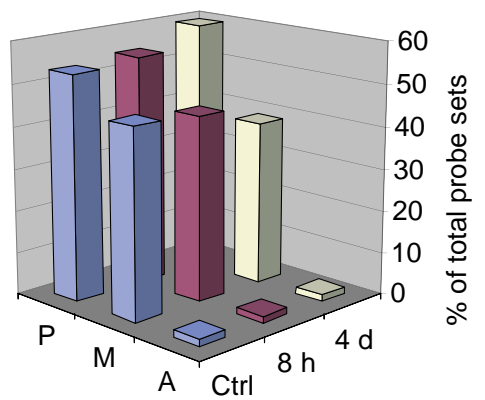

(g)

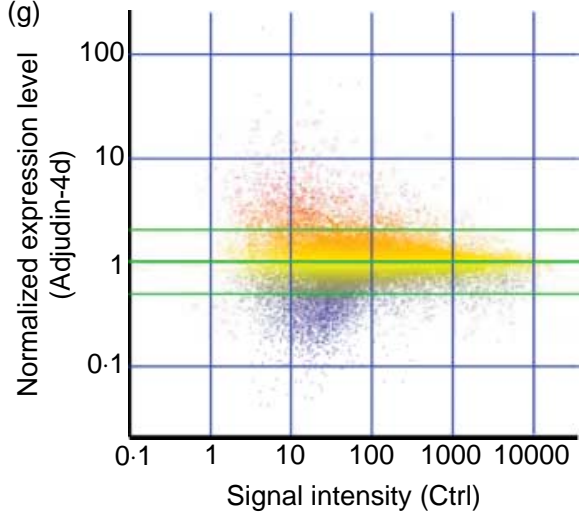

B

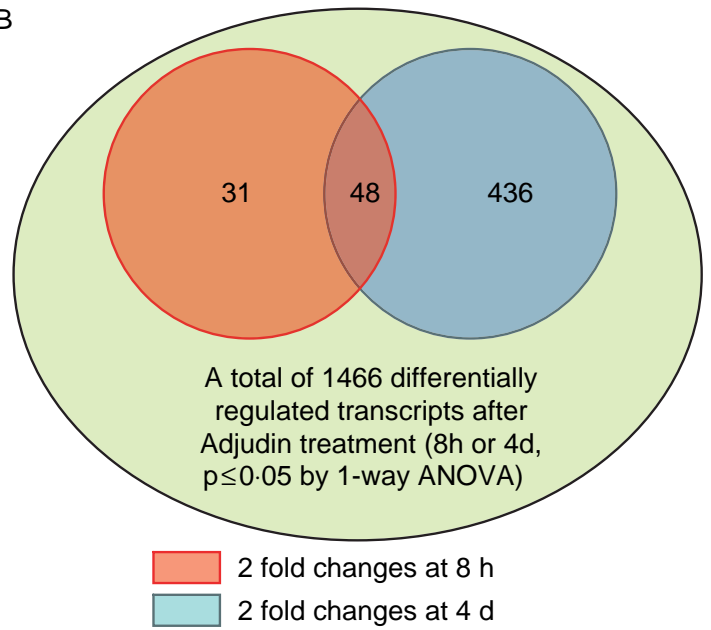


developmental stages and categorized them under the 'germ cell' as an entity. This model was being used to screen target proteins/genes that are pertinent to junction restructuring by accepting their induction in the microarray experiments as physiologically relevant.

We assume the testis weight before Adjudin treatment to be 1 and after treatment to be $m, m<1$.

Control (normal) testis status (A) is : $p+q=1$

Testis status after Adjudin treatment (B) is : $p^{\prime}+q^{\prime}=m$

where $p, p^{\prime}$ are the corresponding Sertoli cell fractions before and after Adjudin treatment, and $q, q^{\prime}$ are the corresponding germ cell fractions before and after Adjudin treatment (assuming $p=p^{\prime}$ since Sertoli cells were not affected by Adjudin; and $0<p \leq m<1,0<q^{\prime} \leq m, q>q^{\prime}$ ).

For a target gene of interest, such as $Z$, its expression level in A (total) is:

$Z_{\mathrm{A}}=p \alpha+q \beta$

and $Z$ expression level in $\mathrm{B}$ (total) is:

$Z_{\mathrm{B}}=p^{\prime} \alpha^{\prime}+q^{\prime} \beta^{\prime}=p \alpha^{\prime}+q \beta^{\prime}$

where $\alpha, \alpha^{\prime}$ are the corresponding expression coefficients for gene $Z$ in Sertoli cells before and after Adjudin treatment in A or $\mathrm{B}$, and $\beta, \beta^{\prime}$ are the corresponding expression coefficients for gene $Z$ in germ cells and after Adjudin treatment in $\mathrm{A}$ or $\mathrm{B}$ with $0 \leq \alpha, \alpha^{\prime}, \beta, \beta^{\prime}$. The expression coefficient of a target gene is the total number of copies of gene $Z \mathrm{mRNA}$ in Sertoli $(\alpha)$ or germ $(\beta)$ cells. For instance, in normal testes occludin is expressed in Sertoli cells only. Therefore, $\alpha_{\text {occludin }}$ is a positive value and $\beta_{\text {occludin }}=0$ (note: the exact value for $\alpha_{\text {occludin }}$ is not required for the following calculations, see below).

From the microarray experiments, changes in the expression level of a target gene $Z$ for testis status B versus control status A were determined as $x$. Because the same amount of total RNA has used in treatment versus control samples, i.e. from the same unit weight of testis tissue (assuming the same unit weight of tissue from different samples contain the same amount of total RNA), the following formula was used:

$$
\begin{aligned}
Z_{\mathrm{B}} / Z_{\mathrm{A}} & =\left(p \alpha^{\prime}+q \beta^{\prime}\right) /(p \alpha+q \beta)=(x / 1) \times(m / 1) \\
& =x m / 1 \times 1=m x
\end{aligned}
$$

We consider the following three possibilities regarding target gene/protein changes during Adjudin-induced germ cell loss from the seminiferous epithelium:

1. If gene $Z$ is only expressed in Sertoli cells: $\beta=0, \beta^{\prime}=0$. Thus, $Z_{\mathrm{B}} / Z_{\mathrm{A}}=\alpha^{\prime} / \alpha=m x$. For example, 4 days after Adjudin treatment, $m$ (weight of testis versus control) $=0.73$ (see Fig. 1Ad), then if $\alpha^{\prime} / \alpha>1, x$ should be $>1 / 0 \cdot 73 \rightarrow x \geq 1 \cdot 4$. This indicates only those genes with $\geq 1 \cdot 4$-fold of change are considered to be induced in the testis after Adjudin treatment. We set the threshold $x \geq 2$, thus $\alpha^{\prime} / \alpha=m x \geq 0 \cdot 73 \times 2 \approx 1.5$. For genes listed in Table 4 , the threshold is actually $x \geq 4$ by day 4 , meaning $\alpha^{\prime} / \alpha \geq 0.73 \times 4 \approx 3$.
2. If gene $Z$ is only expressed in germ cells: $\alpha=0, \alpha^{\prime}=0$

$$
\text { Thus, } \begin{aligned}
\frac{Z_{\mathrm{B}}}{Z_{\mathrm{A}}} & =\frac{(q / \beta \prime)}{(q \beta)}=m x \rightarrow \frac{\beta \prime}{\beta}=m x \frac{q}{q \prime}=m x \frac{(1-p)}{(m-p)} \\
& =x \frac{(m-m p)}{(m-p)}>x
\end{aligned}
$$

(since $m<1$ ).

In this case, the actual fold changes in gene induction in germ cells are greater than the reported fold of changes for $x$.

3. If gene $Z$ is expressed in both Sertoli and germ cells:

$\frac{Z_{\mathrm{B}}}{Z_{\mathrm{A}}}=\frac{(p \alpha \prime+q \prime \beta \prime)}{(p \alpha+q \beta)}=m x$

Herein,

$$
\begin{aligned}
& \min [(p \alpha \prime) /(p \alpha),(q \prime \beta \prime) /(q \beta)] \leq\left(p \alpha \prime+q^{\prime} \beta^{\prime}\right) /(p \alpha+q \beta) \\
& \left.\quad \leq \max \left[\left(p \alpha^{\prime}\right) /(p \alpha),\left(q^{\prime} \beta^{\prime}\right) / q \beta\right)\right]
\end{aligned}
$$

where $\min \left[\left(p \alpha^{\prime}\right) /(p \alpha),\left(q^{\prime} \beta^{\prime}\right) /(q \beta)\right]$ is the minimal value of the two and $\max \left[\left(p \alpha^{\prime}\right) /(p \alpha),\left(q^{\prime} \beta^{\prime}\right) /(q \beta)\right]$ is the maximal value of the two (this is because $p \alpha^{\prime}, q^{\prime} \beta^{\prime}, p \alpha$ and $q \beta$ are all positive values. When $a, b, c, d>0,(a / c) \leq(b / d)$, then $(a / c) \leq(a+b) /(c+d)$ $\leq(b / d)$. Therefore, either $\left(p \alpha^{\prime}\right) /(p \alpha) \geq m x$ or $\left(q^{\prime} \beta^{\prime}\right) /(q \beta) \geq m x$.

When we select the threshold for $x$ such that $m x \geq 1$ (at day $4, x \geq 2$ and $m x \geq 1 \cdot 46$ ), then either $p \alpha^{\prime} / p \alpha \geq m x>1$ $\left(\rightarrow \alpha^{\prime} / \alpha \geq 1\right.$, i.e. induction in Sertoli cells) or $q^{\prime} \beta^{\prime} / q \beta \geq m x>1$ $\left(\rightarrow \beta^{\prime} / \beta \geq q / q^{\prime}>1\right.$, i.e. induction in germ cells). On the other hand, the possibility in (3) can be treated as a mixture of (1) and (2), and on average, $Z_{\mathrm{B}} / Z_{\mathrm{A}}$ should be between the values in (1) and (2) as well. Whichever the possibility, the threshold $x \geq 2$ translates into a minimal 1.5 -fold induction in either germ or Sertoli cells. Table 4 lists those target genes with fourfold of induction $(x \geq 4)$ by day 4 showing Adjudin treatment, which translates into a minimal threefold of induction in either germ or Sertoli cells.

We selected target gene $M y d 116$ for the sake of discussion, which was shown to be induced $3 \cdot 5$-fold at $8 \mathrm{~h}$ and $1 \cdot 7$-fold at day 4 (see Table 3). At $8 \mathrm{~h}, 3.5 \times 0.9=3.15$ and at day 4 , $1.7 \times 0.73=1 \cdot 241$. These results indicate that (1) if this gene is exclusively expressed in Sertoli cells (case 1), there was a $3 \cdot 15$-fold induction at $8 \mathrm{~h}$ (significant) and only $1 \cdot 241$-fold induction at day 4 (not likely to be significant); (2) if this gene is exclusively expressed in germ cells (case 2), there was more than $3 \cdot 5$-fold induction at $8 \mathrm{~h}$ (significant) and more than $1 \cdot 7$ fold induction at day 4 (not certain); (3) if this gene is expressed both in Sertoli and germ cells (case 3), there was an overall $3 \cdot 15$ - to $3 \cdot 5$-fold induction at $8 \mathrm{~h}$ (significant) and $1 \cdot 241$ - to $1 \cdot 7$-fold induction at day 4 (not certain). Collectively, this gene is significantly induced at $8 \mathrm{~h}$ and not likely to be induced significantly at day 4 under all possibilities. Thus, the twofold threshold is a reliable filter to accept or reject any data to assess if a target gene has been induced. Nonetheless, additional cautious steps have to be taken since these data should be validated by techniques of IHC, fluorescent microscopy, and immunoblottings. 


\section{Results}

\section{Microarray data deposition}

The original data sets generated in this report have been deposited at the Gene Expression Omnibus (GEO) data repository website: http://www.ncbi.nih.gov/geo/ with accession number: GSE5131.

\section{Adjudin-induced morphological changes in adult rat testes}

The rationale of selecting the 8-h and 4-day time points postAdjudin treatment for their comparison with control (normal testes) was based on an earlier report that investigated the kinetics of germ cell loss from the epithelium (Chen et al. 2003). By $8 \mathrm{~h}$ after Adjudin treatment, while more than half of the seminiferous tubules examined $(n=600$ from four testes with $\sim 125$ tubules randomly scored per testis) displayed signs of germ cell loss with $\geq 10$ elongating/elongate spermatids found in tubule lumen, most elongating spermatids, round spermatids, and spermatocytes still remained attached to Sertoli cells in the epithelium (see Fig. 1A $b$ vs Fig. 1Aa). This observation also illustrates that even though there was extensive restructuring at the Sertoli-germ cell interface and depleting elongating/ elongate spermatids were found in the lumen, the cellular composition as well as RNAs contributed by Sertoli and germ cells in the samples being analyzed by microarrays were similar to control testes. This argument is supported by the finding that only a $\sim 10 \%$ decline, which was not statistically significant, in testicular weight was detected by 8 h (see Fig. 1Ad). By 4 days after Adjudin treatment, about $80 \%$ of the tubules that were scored were shown to have the number of round spermatid layers reduced by twofold or more with virtually all elongating/ elongate spermatids depleted from the epithelium, and most of the tubules were only populated with round spermatids, spermatocytes, and spermatogonia along with Sertoli cells (Chen et al. 2003; Fig. 1Acvs Fig. 1A $a$, and $b$ ). These results were consistent with a significant loss of testicular weight, by $\sim 27 \%$ at day 4 (Fig. 1Ad). Due to the changes in cellular composition in the tubules as a result of progressive germ cell loss, we sought to correct the expression levels of genes detected by microarray studies by normalizing the results by the testis weight loss since total RNA from whole testes was used for microarray analysis. In our analysis, a threshold was set at twofold, which translated into $\sim 1.5$-fold of net changes $(2 \times 73 \%)$ for 4 -day samples and $\sim 1 \cdot 8$-fold of net changes $(2 \times 90 \%)$ for 8 -h samples, so as to set the basis to 'accept' that a target gene had been 'induced' following Adjudin treatment. A detailed quantitative mathematical analysis of gene expression/protein level changes in concert with cellular composition alteration in the seminiferous epithelium is described in Materials and Methods. Based on this analysis, a twofold induction of a target gene/protein expression has exceeded the threshold that could be simply accounted for by cellular composition alterations in the epithelium by $8 \mathrm{~h}$ 4-day post Adjudin treatment, which would translate into, at the maximum, a 1.5-fold change for a target gene. As such, the focus of this study was placed on genes that were induced by twofold or more in particular by day 4. As expected, many genes appeared to be down-regulated in 4-day samples when most germ cells were depleted from the epithelium, illustrating that these genes were exclusively or abundantly expressed by germ cells. As such, these data (see Supplementary Table 1 and raw data deposited at GEO website), also offer the means to identify germ cell-specific genes.

\section{Assessment of microarray data}

The Affymetrix GeneChip uses external RNA controls, also known as spikes, or spike-in controls, to assess the intermicroarray experimental variations (Bakel \& Holstege 2004, Stoughton 2005). Statistical analysis was performed by comparing data obtained from normal (control) rat testes versus treatment groups by one-way ANOVA for multiple comparisons with multiple test correction (default option), and multiple test correction was set to 'none' using the GeneSpring software (see Materials and Methods). The signals for these controls, as well as for housekeeping genes (e.g. glyceraldehyde-3-phosphate-dehydrogenase (GAPDH) and $\beta$-actin) were consistent between chips (i.e. between different samples) in a single experiment, and were also consistent between samples from different experiments. For testis samples from control rats $(n=3)$ and $8 \mathrm{~h}(n=2)$ after Adjudin treatment, about $55 \%$ of 31099 probe sets were positively detected (i.e. present), about $500(\sim 1.6 \%)$ were absent and $44 \%$ probe sets were detected as marginal, (Fig. 1Ae). However, samples from rats on day 4 ( 4 days, $n=3$ ) after Adjudin treatment have shown an increase in the number of genes present $(\sim 59 \%)$, and a reduction in the number of genes marginal $(\sim 40 \%)$, whereas the number of genes that were absent remained unchanged at $\sim 1 \cdot 6 \%$ (Fig. 1Ae). These results indicated that $\sim 4 \%$ of genes in the rat genome or $\sim 1240$ probe sets became detectable following a longer period of Adjudin treatment (by day 4) and when the epithelium was devoid of virtually all elongating/elongate spermatids, and $\sim 40-50 \%$ round spermatids and $\sim 10-20 \%$ spermatocytes (see Fig. 1A). Indeed, an examination of all probe sets by plotting the normalized expression levels at $8 \mathrm{~h}$ or at day 4 versus their corresponding raw expression levels or signal intensities in control samples revealed a more dispersed distribution for day 4 than $8 \mathrm{~h}$ (Fig. $1 \mathrm{~A} f$ vs $g$ ). In particular, there were more probe sets at day 4 than at $8 \mathrm{~h}$ that fell above or below the twofold threshold lines with signal intensities $>100$, indicating more genes were differentially regulated at the later time point after Adjudin treatment. We filtered out 1466 transcripts which were significantly regulated after Adjudin treatment (control, $8 \mathrm{~h}$ and day 4 ) by one-way ANOVA. There were many more transcripts that were up- or down-regulated by at least twofold in 4-day samples than in $8 \mathrm{~h}$ samples (Fig. 1B), consistent with the data shown in Fig. $1 \mathrm{~A} f$ and $g$. There were 79 transcripts showing more than twofold change in expression; within this group, 31 had more than twofold change detectable only at $8 \mathrm{~h}$ but not at day 4, 48 transcripts 
were regulated by more than twofold both at $8 \mathrm{~h}$ and at day 4 (Fig. 1B). However, 436 transcripts showed more than twofold change only at day 4 but not at $8 \mathrm{~h}$ (Fig. 1B). Selected genes belonging to these three categories ( $\geq$ twofold change at $8 \mathrm{~h}$ only; $\geq$ twofold change at day 4 only; and $\geq$ twofold change at both time points) are summarized in Tables 3-5. Table 4 summarizes the partial list of 436 transcripts with more than fourfold induction. The full list can be found in Supplementary Table 1 (see supplementary data in the online version of the Journal of Endocrinology at http://joe.endocrinology-journals.org/content/vol192/issue3/).

Since many genes related to junction remodeling have previously been studied in the Adjudin model either by RT-PCR or by immunoblotting, a comparison of the expression levels of selected target genes from these experiments versus the results of microarray experiment could assess the reliability of these microarray data. Such genes are tabulated in Table 2. Indeed, these microarray data illustrated that they reproduced or recaptured the expression alterations of these target genes earlier reported from this laboratory. For instance, testin was shown to be induced drastically at day 4 with at least
6- to 15 -fold and $\sim 50$-fold increase in protein and mRNA levels when detected by RIA and northern blots respectively (Grima et al. 2001, Xia \& Cheng 2005), and there was an almost 50 -fold increase in mRNA level detected by microarray as shown in Table 2. Other target proteins, such as $\mathrm{N}$-cadherin, $\beta 1$-integrin, and TGF- $\beta 3$, also yielded consistent results between microarray and earlier RT-PCR and immunoblot data (Table 2).

Expression profiling of the Adjudin-induced germ cell depletion model based on microarray: data validations by quantitative realtime PCR (qPCR), immunoblotting (IB), and immunohistochemistry (IHC)

Genes with more than twofold change in their expression levels were tabulated and grouped by their general functions (Tables 3-5). Among these are cytokines, transcription factors, kinases, phosphatases, genes that regulate ion homeostasis and transport, proteases, protease inhibitors, cell adhesion molecules, and signaling molecules. These tables listed the top-ranked genes from classifications defined in Fig. 1B and these top-ranked

Table 2 Fold changes in the steady-state mRNA levels of selected target genes in Adjudin-treated rat testes during Sertoli-germ cell AJ restructuring which have been characterized in earlier studies

Time after Adjudin treatment (fold changes)

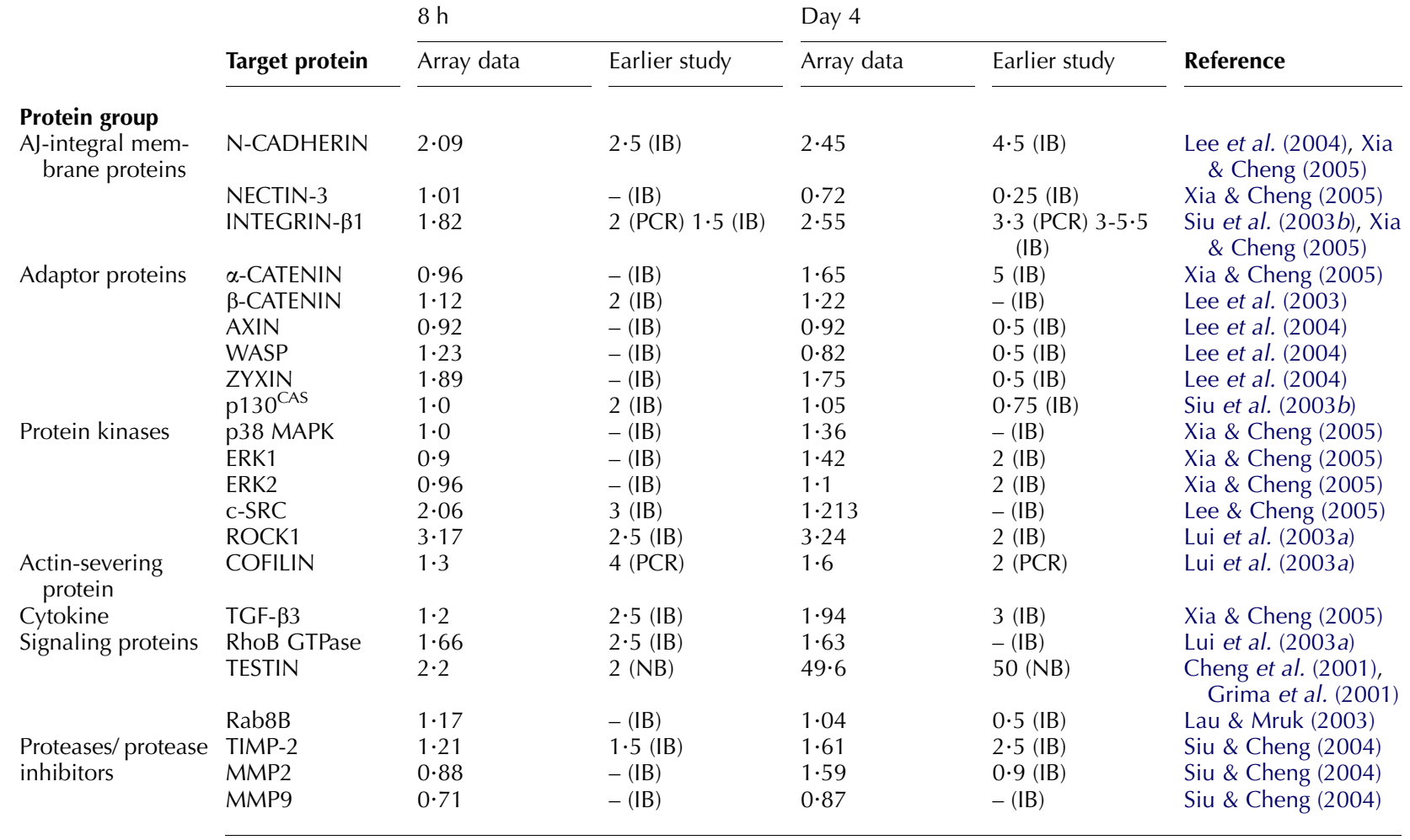

IB, protein level detected by immunoblotting; PCR, steady-state mRNA level detected by RT-PCR; NB, steady-state mRNA level detected by northern blot; numbers indicate fold change relative to control samples which were generated by comparing the densitometrically scanned data; -, no significant changes; MMP, matrix metalloprotease; c-SRC, a non-receptor protein tyrosine kinase of the transforming gene of Rous sarcoma virus; TIMP, tissue inhibitor of metalloprotease; ROCK, Rho-associated protein kinase 1, also known as Rhoß; WASP, Wiskott-Aldrich syndrome protein. 
Table 3 Selected target genes with greater than twofold changes in their steady-state mRNA levels by $8 \mathrm{~h}$ after Adjudin treatment at the time of extensive restructuring at the Sertoli-germ cell interface without the massive germ cell loss from the epithelium

\begin{tabular}{|c|c|c|c|c|c|}
\hline & \multirow[b]{2}{*}{ Accession number } & \multirow[b]{2}{*}{ Symbol } & \multicolumn{2}{|c|}{$\begin{array}{l}\text { Adjudin treatment } \\
\text { (fold changes) }\end{array}$} & \multirow[b]{2}{*}{ Description } \\
\hline & & & $8 \mathrm{~h}$ & Day 4 & \\
\hline \multicolumn{6}{|l|}{ Protein group } \\
\hline \multirow[t]{2}{*}{ Cytokines } & NM_017019 & I/1a & $8 \cdot 6$ & $1 \cdot 9$ & Interleukin $1 \alpha$ \\
\hline & U22520 & Cxcl10 & $3 \cdot 1$ & $1 \cdot 7$ & Chemokine (C-X-C motif) ligand 10 \\
\hline \multirow[t]{5}{*}{ Transcription factors } & NM_012551 & Egr1 & $8 \cdot 5$ & $1 \cdot 5$ & Early growth response 1 \\
\hline & NM_053633 & Egr2 & $5 \cdot 3$ & $1 \cdot 3$ & Early growth response 2 \\
\hline & NM_053328 & Bhlhb2 & $3 \cdot 5$ & $1 \cdot 1$ & $\begin{array}{l}\text { Basic helix-loop-helix domain } \\
\text { containing, class B2 }\end{array}$ \\
\hline & BF407752 & & $2 \cdot 6$ & $1 \cdot 3$ & $\begin{array}{l}\text { AT-rich interactive domain 1A } \\
\text { (Swi1-like; predicted) }\end{array}$ \\
\hline & $\mathrm{BI} 288619$ & Jun & $2 \cdot 1$ & $1 \cdot 9$ & $\begin{array}{l}\text { v-jun sarcoma virus } 17 \text { oncogene } \\
\text { homolog (avian) }\end{array}$ \\
\hline \multirow{2}{*}{$\begin{array}{l}\text { Kinases/ } \\
\text { phosphatases }\end{array}$} & NM_133578 & Cpg21 & $3 \cdot 1$ & $0 \cdot 6$ & MAP-kinase phosphatase (cpg21) \\
\hline & BE120425 & Camk2g & $0 \cdot 4$ & $0 \cdot 6$ & $\begin{array}{l}\text { Calcium/calmodulin-dependent protein } \\
\text { kinase II } \gamma\end{array}$ \\
\hline \multirow{3}{*}{$\begin{array}{l}\text { Cell adhesion } \\
\text { molecules }\end{array}$} & BF558056 & Thsb2 & $4 \cdot 2$ & $1 \cdot 6$ & Thrombospondin 2 (predicted) \\
\hline & AW141214 & Itgav_predicted & $2 \cdot 6$ & $1 \cdot 5$ & $\begin{array}{l}\text { Similar to integrin } \alpha \text { subunit } \\
\quad(\text { LOC296456) }\end{array}$ \\
\hline & Al177059 & Mfap4_predicted & $0 \cdot 4$ & $1 \cdot 5$ & $\begin{array}{l}\text { Microfibrillar-associated protein } 4 \\
\text { (predicted) }\end{array}$ \\
\hline \multirow[t]{3}{*}{$\begin{array}{l}\text { Ion homeostasis } \\
\text { regulators }\end{array}$} & NM_053806 & Kcnk6 & $2 \cdot 8$ & $1 \cdot 9$ & $\begin{array}{l}\text { Potassium channel, subfamily K, } \\
\text { member } 6 \text { (TWIK-2) }\end{array}$ \\
\hline & NM_031604 & Atp6n1a & $2 \cdot 1$ & $1 \cdot 4$ & $\begin{array}{l}\text { ATPase, } \mathrm{H}^{+} \text {transporting, lysosomal } \\
\text { non-catalytic accessory protein } 1 \mathrm{a}\end{array}$ \\
\hline & NM_012740 & Th & $0 \cdot 3$ & $0 \cdot 6$ & Tyrosine hydroxylase \\
\hline \multirow[t]{7}{*}{ Signaling molecules } & $\mathrm{BI} 288701$ & Btg2 & $3 \cdot 9$ & $1 \cdot 3$ & B-cell translocation gene 2, anti-proliferative \\
\hline & $\mathrm{BI} 284349$ & Myd116 & $3 \cdot 5$ & $1 \cdot 7$ & $\begin{array}{l}\text { Myeloid differentiation primary } \\
\text { response gene } 116\end{array}$ \\
\hline & BI294414 & Spry1_predicted & $3 \cdot 4$ & $1 \cdot 6$ & Similar to sprouty 1 (LOC294981), mRNA \\
\hline & $\mathrm{Al} 407755$ & Mesdc1_predicted & $2 \cdot 2$ & $1 \cdot 4$ & Mesoderm development candidate 1 (predicted) \\
\hline & NM_012580 & $\operatorname{Hmox} 1^{-1}$ & $2 \cdot 1$ & $1 \cdot 6$ & Heme oxygenase; Heme oxygenase 1 \\
\hline & Al598401 & Pim1 & $2 \cdot 0$ & $1 \cdot 2$ & Proviral integration site 1 \\
\hline & NM_134413 & Btbd14b & $0 \cdot 5$ & $1 \cdot 0$ & BTB (POZ) domain containing 14B \\
\hline
\end{tabular}

genes fell into the aforementioned functional groups, indicating these genes are likely involved in the event of germ cell depletion from the seminiferous epithelium induced by Adjudin.

In the cytokine group, interleukin (IL) and chemokines are most common in early and late time points after Adjudin treatment. IL- $1 \alpha$ and Cxcl10 showed strong induction by $8 \mathrm{~h}$, but their expression level receded by day 4 (Table 3). Cxcl12 and Il17re were only induced by day 4 (Table 4). Cxcl1, Ccl2, and $\mathrm{Cx} 3 \mathrm{cl} 1$ showed consistent up-regulation at both time points (Table 5).

A number of transcription factors were significantly induced after Adjudin treatment. Some were induced mostly at $8 \mathrm{~h}$, which included Egr1 and Egr2, Bhlhb2, and Jun (Table 3). At day 4, Nupr1 and Pawr became significantly up-regulated versus control (Table 4). Transcription factors, Myc, Stat3, Atf3, and c-fos, also showed strong induction at $8 \mathrm{~h}$ and at day 4 (Table 5). Transcription factors that were induced during Adjudin-induced germ cell loss from the testis as shown in Tables 3-5 were summarized in Table 6 along with their known function in the testis, illustrating these may be potential regulators of junction restructuring events at the Sertoli-germ cell interface, pertinent to spermatogenesis.

Only a few genes displayed more than twofold reduction in their expression levels by $8 \mathrm{~h}$ after Adjudin treatment, and these include Camk2g, Th, and Btbd14b (Table 3). The number of genes showing a reduced expression by $8 \mathrm{~h}$ or 4 days after Adjudin treatment was considerably less than those displaying an increase in their expression (Tables 3-5, Supplementary Table 1).

We selected a number of target genes to validate their expression changes detected by microarray using other methods as follows: (1) transcription factors: Stat3, Jun, Bhlhb2, and c-fos (Fig. 2A and B); (2) cytokines and related molecules: IL-1 $\alpha$, Cxcl10, and Tnfrsfla (Fig. 2C); and (3) proteases and protease inhibitors: Prss11 and Serping1 (Fig. 2D). The fold changes determined by qPCR were consistent with microarray data for all nine genes selected for analysis (Fig. 2 vs Tables 3-5). For instance, both Prss11 and 
Table 4 Selected target genes with greater than twofold changes in their steady-state mRNA levels by day 4 after Adjudin treatment at the time of germ cell loss from the seminiferous epithelium

\begin{tabular}{|c|c|c|c|c|c|}
\hline & \multirow[b]{2}{*}{ Accession number } & \multirow[b]{2}{*}{ Symbol } & \multicolumn{2}{|c|}{$\begin{array}{l}\text { Adjudin treatment } \\
\text { (fold changes) }\end{array}$} & \multirow[b]{2}{*}{ Description } \\
\hline & & & $8 \mathrm{~h}$ & Day 4 & \\
\hline \multicolumn{6}{|l|}{ Protein group } \\
\hline \multirow[t]{2}{*}{ Cytokines/receptors } & BF283398 & Cxcl12 & $1 \cdot 0$ & $5 \cdot 3$ & Chemokine (C-X-C motif) ligand 12 \\
\hline & BM383766 & Il17re & $1 \cdot 0$ & $5 \cdot 1$ & $\begin{array}{l}\text { Similar to interleukin } 17 \text { receptor } \\
\text { E isoform } 1\end{array}$ \\
\hline \multirow[t]{2}{*}{ Transcription factors } & NM_053611 & Nupr1 & $1 \cdot 4$ & $5 \cdot 4$ & Nuclear protein 1 \\
\hline & U05989 & Pawr & $1 \cdot 3$ & $4 \cdot 1$ & PRKC, apoptosis, WT1, regulator \\
\hline \multirow[t]{6}{*}{$\begin{array}{l}\text { Ion homeostasis reg- } \\
\text { ulators }\end{array}$} & BG378926 & S100a11_predicted & $0 \cdot 9$ & $7 \cdot 3$ & $\begin{array}{l}\text { S100 calcium-binding protein A11 } \\
\text { (calizzarin) (predicted) }\end{array}$ \\
\hline & BF401956 & Trfr2_predicted & $0 \cdot 8$ & $6 \cdot 5$ & $\begin{array}{l}\text { Similar to transferrin receptor protein } 2 \\
\quad \text { (TfR2) (LOC288562) }\end{array}$ \\
\hline & BF412731 & Pdyn & $1 \cdot 0$ & $6 \cdot 2$ & Prodynorphin \\
\hline & NM_130741 & Lcn2 & $1 \cdot 2$ & $5 \cdot 9$ & Lipocalin 2 \\
\hline & NM_053469 & Hamp & $2 \cdot 0$ & $4 \cdot 9$ & Hepcidin antimicrobial peptide \\
\hline & NM_012733 & Rbp1 & $1 \cdot 2$ & $4 \cdot 1$ & Retinol-binding protein 1 \\
\hline \multirow{5}{*}{$\begin{array}{l}\text { Proteases/ protease } \\
\text { inhibitors }\end{array}$} & NM_031531 & Spin2C & $1 \cdot 5$ & $26 \cdot 0$ & Serine protease inhibitor \\
\hline & NM_053819 & Timp1 & $1 \cdot 7$ & $15 \cdot 0$ & Tissue inhibitor of metalloproteinase 1 \\
\hline & BF41̄1331 & Serpinb1a_predicted & $0 \cdot 9$ & $6 \cdot 8$ & $\begin{array}{l}\text { Similar to serine (or cysteine) proteinase } \\
\text { inhibitor, clade } B \text {, member } 1 \mathrm{~b}\end{array}$ \\
\hline & AW915763 & Serping1 & $1 \cdot 3$ & $4 \cdot 9$ & $\begin{array}{l}\text { Serine (or cysteine) proteinase inhibitor, } \\
\text { clade } \mathrm{G}(\mathrm{C} 1 \text { inhibitor), member } 1, \\
\text { (angioedema, hereditary) }\end{array}$ \\
\hline & NM_031721 & Prss11 & $1 \cdot 0$ & $4 \cdot 1$ & Protease, serine, 11 \\
\hline \multirow[t]{3}{*}{$\begin{array}{l}\text { Cytoskeleton inter- } \\
\text { acting proteins }\end{array}$} & BI296155 & & $1 \cdot 6$ & $5 \cdot 6$ & $\begin{array}{l}\text { Filamin, } \beta \text {, transcript variant } 3 \\
\quad \text { (Flnb) predicted }\end{array}$ \\
\hline & BE109711 & Lcp1_predicted & $1 \cdot 1$ & $4 \cdot 8$ & $\begin{array}{l}\text { Similar to lymphocyte cytosolic } \\
\text { protein } 1 \text { (LOC306071) }\end{array}$ \\
\hline & BM392410 & Myh9 & $1 \cdot 3$ & $4 \cdot 6$ & Myosin, heavy polypeptide 9 \\
\hline $\begin{array}{l}\text { Cell adhesion } \\
\text { molecules }\end{array}$ & NM_133298 & $G p n m b$ & $1 \cdot 6$ & $13 \cdot 6$ & Glycoprotein (transmembrane) $\mathrm{nmb}$ \\
\hline \multirow[t]{12}{*}{ Signaling molecules } & NM_133624 & Gbp2 & $1 \cdot 9$ & $5 \cdot 2$ & $\begin{array}{l}\text { Guanylate-binding protein } 2 \\
\text { interferon-inducible }\end{array}$ \\
\hline & AW917760 & & $1 \cdot 3$ & $7 \cdot 9$ & Similar to myoferlin (Fer-1-like protein 3) \\
\hline & H31511 & Trim2 & $1 \cdot 5$ & $6 \cdot 0$ & $\begin{array}{l}\text { Tripartite motif protein } 2 \\
\quad \text { (protein ubiquitination) }\end{array}$ \\
\hline & NM_019386 & $\operatorname{Tgm} 2$ & $1 \cdot 2$ & $4 \cdot 1$ & $\begin{array}{l}\text { Tissue-type transglutaminase, } \\
\text { C polypeptide }\end{array}$ \\
\hline & BF282318 & & $1 \cdot 6$ & $5 \cdot 4$ & $\begin{array}{l}\text { Similar to Bq135360 (LOC292922; } \\
\text { acute-phase response) }\end{array}$ \\
\hline & BM387864 & & $1 \cdot 8$ & $5 \cdot 3$ & Similar to FLI-LRR-associated protein-1 \\
\hline & Y00480 & $R T 1-D a$ & $1 \cdot 1$ & $5 \cdot 3$ & Rat MHC class II RT1, locus Da \\
\hline & BI285865 & Tagln2_predicted & $1 \cdot 4$ & $5 \cdot 3$ & $\begin{array}{l}\text { Similar to transgelin 2; SM22- } \alpha \text { homolog } \\
\quad(\text { LOC304983) }\end{array}$ \\
\hline & M25719 & Pam & $0 \cdot 9$ & $5 \cdot 1$ & $\begin{array}{l}\text { Peptidylglycine } \alpha \text {-amidating } \\
\text { monooxygenase }\end{array}$ \\
\hline & $\mathrm{BI} 274355$ & Olfm/3_predicted & $1 \cdot 0$ & $4 \cdot 9$ & Olfactomedin-like 3 (predicted) \\
\hline & D88250 & $C 1 s$ & $1 \cdot 1$ & $4 \cdot 8$ & $\begin{array}{l}\text { Complement component } 1, \mathrm{~s} \\
\text { subcomponent }\end{array}$ \\
\hline & $\mathrm{BI} 285347$ & C4a & $1 \cdot 2$ & $6 \cdot 0$ & Palmitoyl-protein thioesterase 2 \\
\hline
\end{tabular}

Serping1 showed relatively little change at $8 \mathrm{~h}$ but were induced by about four- to fivefold at day 4 (Table 4) in microarray analysis, and results from qPCR showed that at $8 \mathrm{~h}$, the steady-state mRNA levels of these two genes were not significantly different from controls but were induced by approximately fivefold at day 4 (Fig. 2D). Since these nine genes were randomly selected from Tables 3-5 for analysis, it is logical to conclude that the fold change detected for other genes listed in these tables is reliable. Furthermore, the changes in the steady-state mRNA levels of cytokines reported in Tables 3-5, such as Cxcl1, were confirmed using cytokine antibody array (data not shown).

Several additional target genes that were or were not listed in the tables were also selected, and changes in their protein levels 
Table 5 Selected target genes with greater than twofold changes in their steady-state mRNA levels by $8 \mathrm{~h}$ and day 4 after Adjudin treatment

\begin{tabular}{|c|c|c|c|c|c|}
\hline & \multirow[b]{2}{*}{ Accession number } & \multirow[b]{2}{*}{ Symbol } & \multicolumn{2}{|c|}{$\begin{array}{l}\text { Adjudin treatment } \\
\text { (fold change) }\end{array}$} & \multirow[b]{2}{*}{ Description } \\
\hline & & & $8 \mathrm{~h}$ & Day 4 & \\
\hline \multicolumn{6}{|l|}{ Protein group } \\
\hline \multirow[t]{7}{*}{ Cytokines/receptors } & NM_030845 & $\mathrm{CxCl1}$ & $62 \cdot 6$ & $6 \cdot 8$ & Chemokine (C-X-C motif) ligand 1 \\
\hline & NM 031530 & $\mathrm{CCl} 2$ & $8 \cdot 1$ & $5 \cdot 2$ & Chemokine (C-C motif) ligand 2 \\
\hline & NM_017020 & $1 / 6 r$ & $4 \cdot 0$ & $8 \cdot 1$ & Interleukin 6 receptor \\
\hline & BI303379 & Tnfrsf12a & $3 \cdot 8$ & $8 \cdot 4$ & $\begin{array}{l}\text { Tumor necrosis factor receptor } \\
\text { superfamily, member } 12 \mathrm{a}\end{array}$ \\
\hline & NM_134455 & $C \times 3 c / 1$ & $3 \cdot 2$ & $5 \cdot 3$ & Chemokine (C-X3-C motif) ligand 1 \\
\hline & NM_030997 & $V g f$ & $3 \cdot 0$ & $16 \cdot 1$ & VGF nerve growth factor inducible \\
\hline & NM_013091 & Tnfrsf1a & $2 \cdot 2$ & $6 \cdot 1$ & $\begin{array}{l}\text { Tumor necrosis factor receptor } \\
\text { superfamily, member } 1 \mathrm{a}\end{array}$ \\
\hline \multirow[t]{6}{*}{ Transcription factors } & BF415939 & $c-f o s$ & $26 \cdot 8$ & $3 \cdot 5$ & c-fos oncogene \\
\hline & NM_012912 & Atf3 & $15 \cdot 1$ & $11 \cdot 2$ & Activating transcription factor 3 \\
\hline & Al7̄̄ 6248 & & $3 \cdot 4$ & $4 \cdot 9$ & $\begin{array}{l}\text { Similar to RIKEN cDNA 9230117N10 } \\
\text { (LOC361749), nucleus protein } \\
\text { (predicted) }\end{array}$ \\
\hline & NM_012591 & Irf1 & $2 \cdot 1$ & $4 \cdot 1$ & Interferon regulatory factor 1 \\
\hline & NM_012603 & Myc & $2 \cdot 1$ & $2 \cdot 7$ & $\begin{array}{l}\text { v-myc avian myelocytomatosis viral } \\
\text { oncogene homolog }\end{array}$ \\
\hline & BE113920 & Stat3 & $2 \cdot 0$ & $2 \cdot 6$ & $\begin{array}{l}\text { Signal transducer and activator of } \\
\text { transcription } 3\end{array}$ \\
\hline \multirow{3}{*}{$\begin{array}{l}\text { Cell adhesion } \\
\text { molecules }\end{array}$} & Al406660 & Thbs1 & $6 \cdot 0$ & $2 \cdot 4$ & Thrombospondin 1 \\
\hline & BE110753 & Itga6 & $3 \cdot 3$ & $3 \cdot 6$ & Integrin $\alpha 6$ \\
\hline & $\mathrm{Al} 408095$ & Smagp & $2 \cdot 9$ & $4 \cdot 6$ & Small cell adhesion glycoprotein \\
\hline \multirow[t]{2}{*}{ Proteases } & NM_013151 & Plat & $2 \cdot 8$ & $3 \cdot 1$ & Plasminogen activator, tissue type \\
\hline & $\mathrm{Al} 232474$ & Ctsl & $2 \cdot 5$ & $3 \cdot 1$ & Cathepsin L \\
\hline \multirow[t]{3}{*}{ Transporters } & NM_012532 & $C p$ & $2 \cdot 7$ & $4 \cdot 2$ & Ceruloplasmin \\
\hline & NM_031325 & Ugdh & $2 \cdot 6$ & $3 \cdot 6$ & UDP-glucose dehydrogenase \\
\hline & NM_053318 & $H p x$ & $4 \cdot 0$ & $46 \cdot 2$ & Hemopexin \\
\hline \multirow[t]{11}{*}{ Signaling molecules } & Al17 6519 & Ler3 & $9 \cdot 7$ & $4 \cdot 3$ & Immediate early response 3 \\
\hline & AA800587 & $G p \times 2$ & $2 \cdot 8$ & $7 \cdot 0$ & Glutathione peroxidase 2 \\
\hline & BF420334 & Rab20_predicted & $2 \cdot 7$ & $2 \cdot 5$ & Similar to rab20 (LOC364641) mRNA \\
\hline & Al703807 & Crim1_predicted & $2 \cdot 3$ & $5 \cdot 9$ & Cysteine-rich motor neuron 1 (predicted) \\
\hline & AA901350 & & $2 \cdot 3$ & $5 \cdot 9$ & $\begin{array}{l}\text { Guanylate nucleotide-binding protein } 3 \\
\text { (predicted) }\end{array}$ \\
\hline & U16858 & Testin & $2 \cdot 2$ & $49 \cdot 6$ & Testin \\
\hline & BE099056 & Grtp1_predicted & $2 \cdot 2$ & $3 \cdot 0$ & $\begin{array}{l}\text { Similar to GH-regulated TBC protein } 1 \\
\quad \text { (LOC361180), mRNA }\end{array}$ \\
\hline & BF412519 & Ripk2_predicted & $2 \cdot 2$ & $4 \cdot 1$ & $\begin{array}{l}\text { Receptor (TNFRSF)-interacting } \\
\text { serine-threonine kinase } 2 \text { (predicted) }\end{array}$ \\
\hline & NM_054008 & $\operatorname{Rgc} 32$ & $2 \cdot 1$ & $2 \cdot 8$ & $\begin{array}{l}\text { Response gene to Complement } 32 \\
\quad \text { (cyclin-dependent kinase regulation) }\end{array}$ \\
\hline & BE113215 & Trim47_predicted & $2 \cdot 1$ & $4 \cdot 0$ & $\begin{array}{l}\text { Tripartite motif protein } 47 \\
\quad \text { (predicted; protein ubiquitination) }\end{array}$ \\
\hline & BI294994 & Optn & $2 \cdot 1$ & $2 \cdot 5$ & Optineurin \\
\hline
\end{tabular}

were examined by IB and IHC. The cathepsin L (Ctsl) steadystate mRNA level was shown to be induced by $2 \cdot 5-$ and $3 \cdot 1$-fold by 8 h and 4 days respectively, by microarray (Table 5 ). Consistent with these findings, the cathepsin L protein level was shown to be stimulated by approximately two- and fivefold by $8 \mathrm{~h}$ and 4 days respectively, by IB analysis (Fig. 3A $a$ ). The signals were also shown to be stimulated in IHC (Fig. 3A $b, c$ and d). $\alpha_{2}-$ Macroglobulin $\left(\alpha_{2}-\mathrm{MG}\right)$ was found to be induced by $1 \cdot 1$-fold at $8 \mathrm{~h}$ and threefold at day 4 (Supplementary Table 1), and this pattern of induction was consistent with the IB and IHC data (Fig. 3B). The testin steady-state
mRNA level was induced by approximately twofold at $8 \mathrm{~h}$ and $\sim 50$-fold at day 4 (Tables 2 and 5), with its protein level induced by approximately sixfold at day 4 (Table 2 and Fig. 3Ca). These results are also consistent with data obtained by IHC (Fig. 3Cd versus Fig. 3Cbc). Changes in the expression of a tight junction integral membrane protein, claudin 3, were also examined. For example, claudin 3 displayed no change in protein level and distribution after Adjudin treatment (Fig. 3D). These results were consistent with microarray data, which showed no significant changes on claudin 3 , claudin 1 , and occludin 
Table 6 Summary of transcription factors that are significantly induced during Adjudin-induced anchoring junction restructuring in the testis

Other names KO phenotype Function

Transcription factors

Egr1

Egr2

Bhlhb2

NGFI-A/Krox-

24/zif/268

Krox-20

SHARP-

2/Stra13/DEC1

Jun

n.a.

Nupr1

Nuclear protein p8

Normal; increased

Pawr

Par-4

c-fos

n.a.

Atf3

Irf1
LRF-1/LRG-21/CRG- 5/ TI-241

n.a.

n.a.

Stat3

n.a.
Female infertile; male fertile or sterile

Perinatal

lethality

Normal, aging

mice develop autoimmune disease

Embryonic-

perinatal

lethality sensitivity to lipopolysaccharide

Splenomegaly

Regulates LH- $\beta$ expression

Brain development

Transcription repressor; required for cytokine production; activated by TGF- $\beta$

Multiple functions; JNK signaling; stagespecific expression

Enhances TGF- $\beta 1$-smad signaling

Transcription corepressor; mediates TNF $\alpha-n . k$. induced apoptosis

Reduced viability and size, impaired gametogenesis

Normal

Normal

Embryonic lethality; heterozygous females with reduced fertility Embryonic lethality

n.k.

n.k. basement membrane; stage-specific

Stress response

Regulates interferon expression

Multiple functions; testosterone and FSH
Studies in testes

\section{References}

Cultured Sertoli cells; Lee et al. (1996), Topilko et al. (1998), Leydig cells

O'Donovan et al. (1999)

Schneider-Maunoury et al. (1993), Swiatek \& Gridley (1993)

Sun et al. (2001), Zawel et al. (2002)

Spermatogonia, pre- Alcivar et al. (1990), Johnson et al. (1993), leptotene spermaSchultz et al. (1995) tocytes

$$
\text { n.k. }
$$

Mallo et al. (1997), Garcia-Montero et al. (2001), Vasseur et al. (2003)

Garcia-Cao et al. (2003), Lafuente et al. (2003), Sushma Gurumurthy (2004), Goswami et al. (2006)

Regulates Sertoli cell differentiation on

Multiple functions; regulates IL-6 and IFN- Cultured Sertoli cells Jenab \& Morris (1997), Takeda et al expression induce c-Myc expression in cultured Sertoli cells

$\gamma$ mediated gene expression in Sertoli (1997), Takeda \& Akira (2000)

Cultured Sertoli cells Johnson et al. (1992) Papadopoulos \& Dym (1994), Schultz et al. (1995)

Milde-Langosch (2005)

n.k.

Hai \& Hartman (2001), Hartman et al. (2004)

Cultured Sertoli cells Matsuyama et al. (1993), Tanaka \& Taniguchi (2000), Sato et al. (2001)

Spermatogonia Koji et al. (1988), Davis et al. (1993), Lim et al. (1994), Lim \& Hwang (1995) 

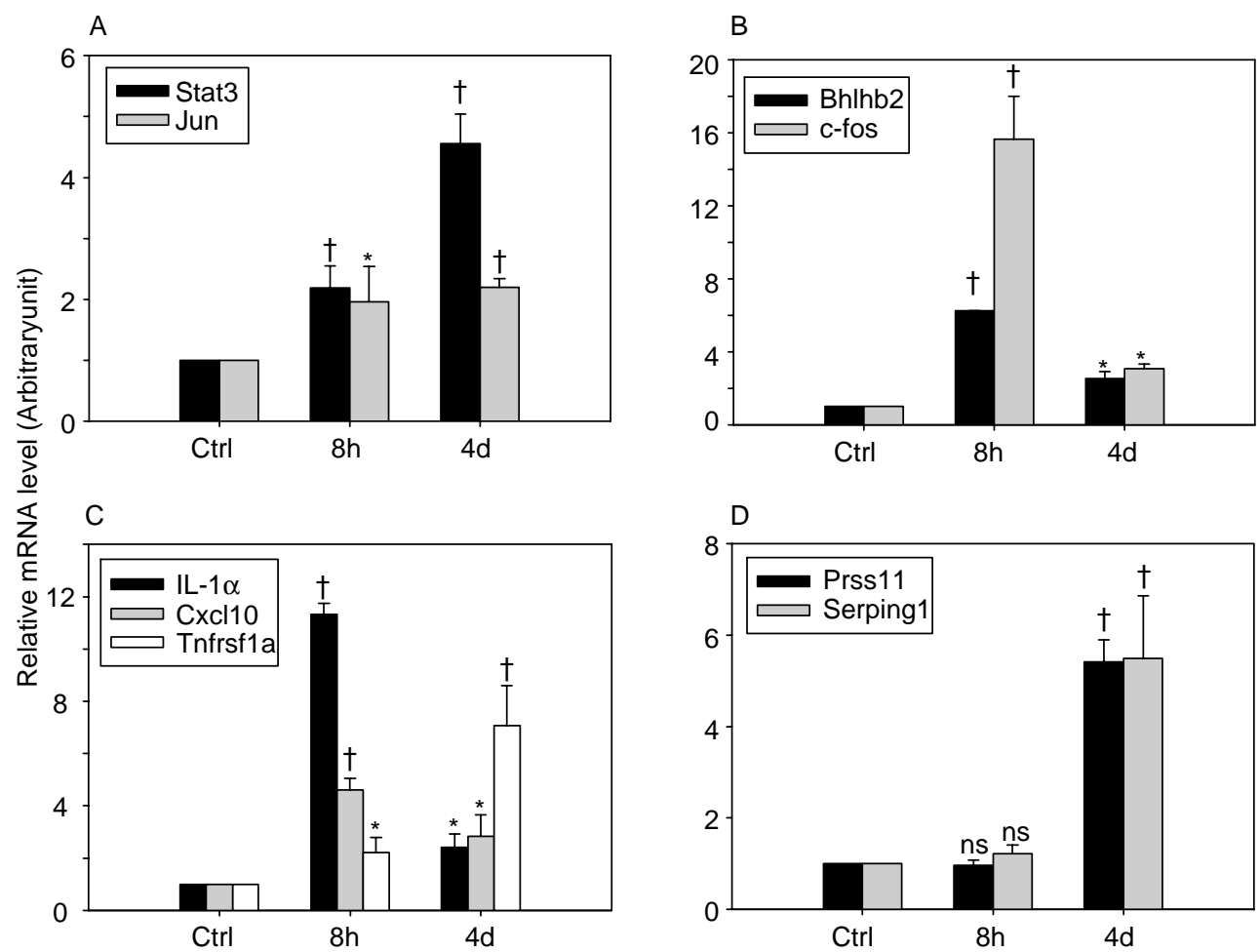

Figure 2 Real-time RT-PCR quantification of the steady-state mRNA levels of selected target genes after Adjudin treatment by $8 \mathrm{~h}$ and day 4 versus control (Ctrl, normal testes). Note that the relative mRNA levels (fold changes against control) determined by real-time PCR for these nine genes were consistent with results of microarray experiments (see Tables $2-4$ ). The activation of selected target genes during Adjudin-induced germ cell loss from the seminiferous epithelium as described herein have not previously been reported. ns, Not significantly different by ANOVA, ${ }^{*} P<0 \cdot 05 ;{ }^{\dagger} P<0 \cdot 01$.

after Adjudin treatment (data not shown; see raw data in GEO depository). However, other tight junction (TJ) proteins displayed significant changes at day 4 . For instance, JAM-A and claudin 11 showed a $\sim 1 \cdot 8$-fold increase in expression at day 4 (but no change at $8 \mathrm{~h}$ ), and claudin 4 expression level was reduced by as much as $50 \%$ at day 4 (data not shown; see raw data in GEO depository). These results also illustrate the expression of different $\mathrm{TJ}$ proteins were differentially regulated.

\section{Clustering analysis to identify genes that are closely regulated}

We performed unsupervised hierarchical clustering of the eight samples (Ctrl $(n=3), 8 \mathrm{~h}(n=2)$, and day $4(n=3))$ and the 1466 transcripts using the GeneSpring software and the results were summarized in Fig. 4. The branches of the dendrogram were removed from this presentation, but the main subtrees were illustrated by a line showing five different domains (Figure 4a-e), which were again classified into two larger subtrees of $\mathrm{i}$ and ii. This clustering analysis grouped similarly regulated genes. Two representative regions in the dendrogram were selected and examined in detail in Fig. 4B and C, which showed the induced expression of these genes at day 4 but not at $8 \mathrm{~h}$, and reduced expression at $8 \mathrm{~h}$ but mildly increased expression at day 4 respectively.
Identifying and ranking signaling pathways activated by Adjudin in the testis

We next used Pathway Express (PE) to identify the signaling pathways that were activated during Adjudin-induced germ cell loss from the epithelium (Draghici et al. 2003a, b, Khatri et al. 2004, 2005; Table 7). PE is a tool in the Onto-Tools ensemble (Wayne State University, see http://vortex.cs.wayne.edu (Draghici et al. 2003a,b, Khatri et al. 2004, 2005)) that was designed to identify the signaling pathways that contain the corresponding target genes. A list of genes with their fold changes were first submitted to the system, which then performed a search and built a list of all associated pathways. The system calculated an impact factor to rank the pathways based on the importance of a gene in the pathway (indicating how much it affects the downstream signaling), the strength or fold of change of the gene, and percentage of genes in the pathway that were included in this list of genes (Khatri et al. 2004, 2005). The probe set ID number with the corresponding fold changes at $8 \mathrm{~h}$ or at day 4 were tabulated (all 1466 probe sets) and imported into the program and the top signaling pathways were identified. At $8 \mathrm{~h}$, the top-ranking pathways identified based on the impact factor were phosphatidylinositol (PI) signaling (7/43: input genes/ pathway genes), focal adhesion (13/109), cytokine-cytokine receptor interactions (16/110), MAPK signaling pathway 

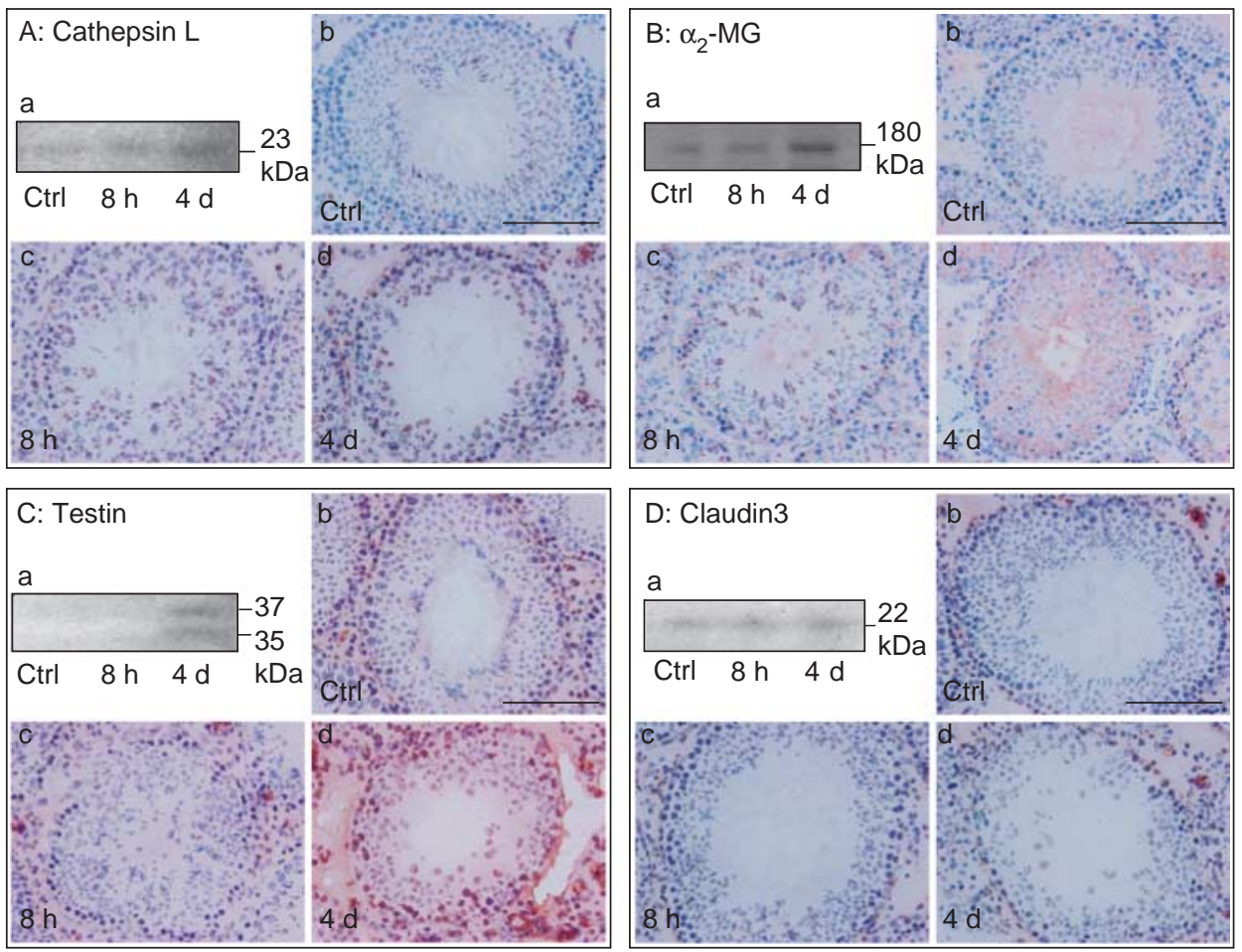

Figure 3 A study by immunoblotting and immunohistochemistry to assess changes in selected target proteins in rat testes after Adjudin treatment to validate microarray results. (A; a) Immunoblot analysis of cathepsin L in control (Ctrl), 8-h and 4-day rat testes. (b-d) Immunohistochemistry localization of cathepsin $\mathrm{L}$ in control, 8-h and 4-day testis respectively. Bar in $b=70 \mu \mathrm{m}$, also applies to (c-d), as well as (b-d) in (B), (C) and (D). (B-D) Corresponding immunoblot analysis and immunohistochemistry results for $\alpha_{2}$-macroglobulin $\left(\alpha_{2}-\mathrm{MG}\right)$, testin, and claudin 3 respectively, similar to those shown in (A). The induction of testin during Adjudin-induced germ cell loss from the testis is consistent with earlier reports (Grima et al. 1997, Cheng et al. 2001), but changes of $\alpha_{2}-M G$ and cathepsin or the unresponsiveness of claudin 3 have not been reported.

(21/153), tight junction (10/185), apoptosis (11/66), and calcium signaling pathway (13/161; Table 7). At day 4, the top-ranking pathways were phosphatidylinositol signaling, focal adhesion, cytokine-cytokine receptor interactions, tight junction, MAPK signaling pathway, apoptosis, and calcium signaling pathway (Table 7). The numbers of input and pathway genes for $8 \mathrm{~h}$ and day 4 were the same. Collectively, these results were consistent with recently published findings that these are putative signaling pathways that regulate Sertoli-germ cell adhesion (Lui et al. 2003a, Siu et al. 2003b, 2005, Wong et al. 2005, Xia \& Cheng 2005, Zhang et al. 2005) and probably suggest that these are the most important signaling events taking place in the testis after the rats were treated with Adjudin.

\section{Discussion}

Junction restructuring during spermatogenesis is a complex process regulated by a multitude of molecules

This microarray study has identified genes that are differentially regulated during Adjudin-induced AJ restructuring at the Sertoli-germ cell interface prior to the massive physical dislodging of germ cells, at $8 \mathrm{~h}$ vs day 4, when virtually all elongating/elongate spermatids and most round spermatids and spermatocytes were depleted from the epithelium, and compared with normal testes. Among these genes, we summarize those with most drastic induction in the steady-state mRNA level versus controls and categorize them into functional groups (Tables 3-5). Although only the expression data were obtained using this genome-wide gene profiling approach without considering translational and post-translational regulations, these genes nonetheless are potentially key players in the junction restructuring events at spermatogenesis since recent studies using specific inhibitors and the other models involving steroid implants to suppress endogenous testosterone level in the testis have clearly demonstrated that data obtained from this model is relevant to the in vivo physiology of Sertoli-germ cell interactions, particularly cell adhesion regulation (Lui et al. 2003a, Siu et al. 2003b, 2005, Siu \& Cheng 2004, Lee \& Cheng 2005, Lee et al. 2005, Wong et al. 2005, Xia \& Cheng 2005). The identified genes include those that are involved in signaling and/or regulatory functions pertinent to the junction restructuring: (1) cell-cell communication, including cytokine-mediated signaling, ion transport and homeostasis; (2) intracellular signaling mediated via kinases, phosphatase, and adaptors; (3) structurally important cell adhesion and 

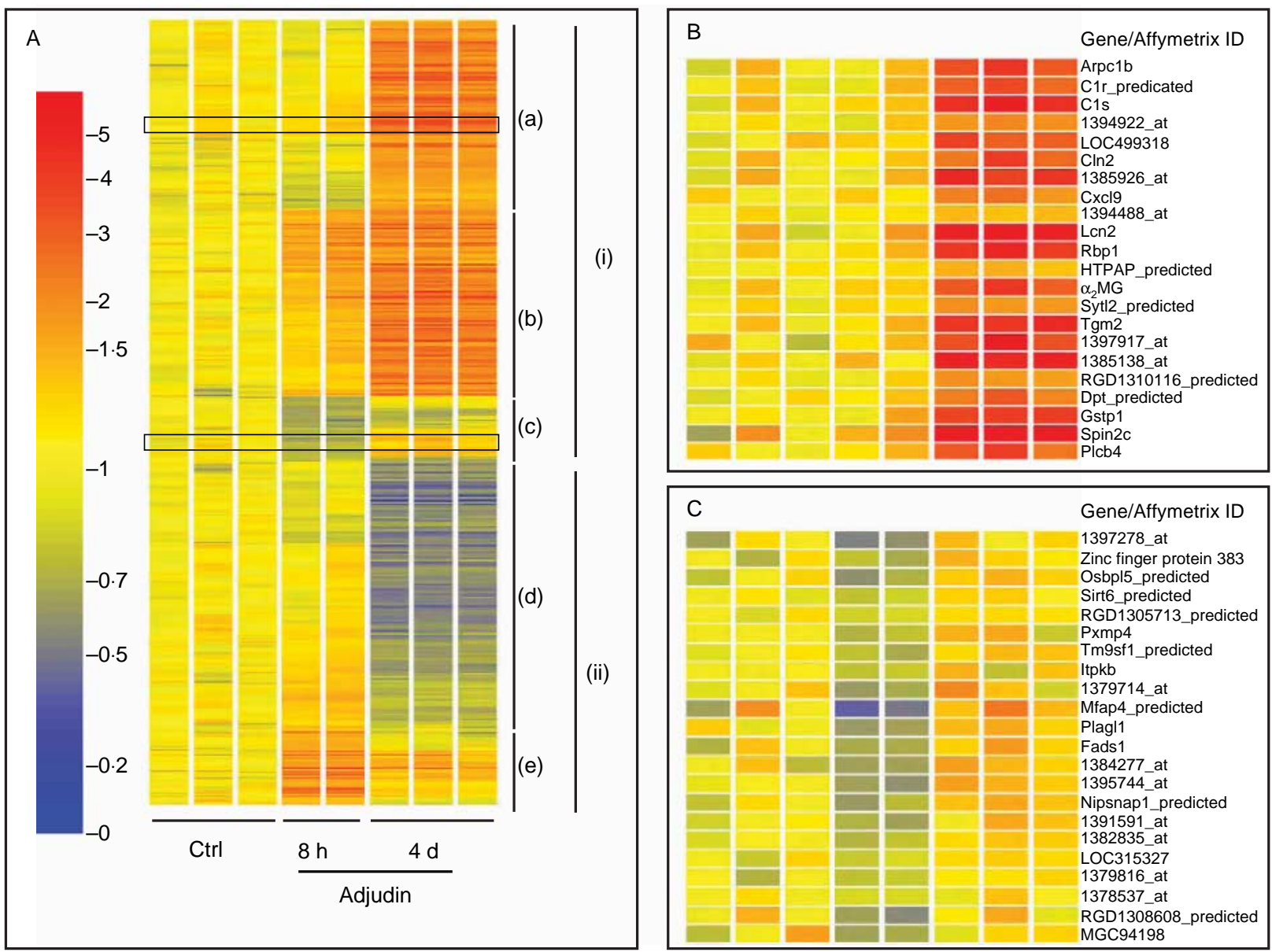

Figure 4 Hierarchical clustering of 1466 differentially regulated transcripts in rat testes from eight samples ( $n=3$ for control (Ctrl) testes, $n=2$ for $8 \mathrm{~h}, n=3$ for day 4 following Adjudin treatment). (A) Expression fold changes are depicted by the color map in the left panel. The dendrogram in the right panel illustrates that these 1466 probe sets displayed consistent patterns of up- or down-regulation by $8 \mathrm{~h}$ or 4 days after Adjudin treatment versus controls. Note that these patterns are consistent across different chips using different batches of samples within the same group. Five domains can be identified (a-e) that comprise the entire spectrum, which are also the five subtrees in the dengrogram (branches were removed without distracting the main diagram). These domains can be further grouped into two categories of $\mathrm{i}$ and ii, the subtrees at a higher level, which show a more pronounced mRNA induction at day 4 than $8 \mathrm{~h}$ (i) and vice versa (ii). Two boxed areas shown in (A) were selected and examined in detail and shown in (B) (top panel) and (C) (bottom panel). (B) Selected genes with significantly increased expression at day 4 but not at $8 \mathrm{~h}$. (C) Selected genes with significant reduced expression at $8 \mathrm{~h}$ but not at day 4 . The gene/Affymetrix IDs are listed on the right side of each row.

cytoskeleton-related proteins; (4) proteases and protease inhibitors that affect cell matrix, cell-cell and intracellular interactions; and (5) transcription factors. Except for the last group and ion transport/homeostasis proteins, genes belonging to all other groups have been investigated and shown to be involved in regulating junction restructuring in earlier studies (Mruk \& Cheng 2004b). We had since proposed a junction restructuring theory to describe the mechanisms of germ cell movement in the seminiferous epithelium (Mruk \& Cheng 2004b). This theory was formulated based on studies of in vivo (e.g. Adjudin model, cadmium model), and in vitro (e.g. Sertoli-germ cell co-cultures) which have also identified several putative signaling pathways that are known to regulate Sertoli-germ cell adhesion (Lui et al. 2003a, Siu et al. 2003b,
Lee et al. 2005), which are also confirmed in this microarray study. Perhaps the most important of all, results of this gene profiling study have unraveled two important lines of research pertinent to Sertoli-germ cell adhesion regulation. First, additional mechanistic pathways that can be potentially crucial to Sertoli-germ cell adhesion have been identified. For instance, this gene profiling study has demonstrated that PI-3 kinase, FAK, and MAPK are the leading signaling molecules that are involved in the Adjudin-induced Sertoligerm cell AJ restructuring, confirming results of earlier studies (Lui et al. 2003a, Siu et al. 2003b, 2005, Wong et al. 2005, Xia \& Cheng 2005, Zhang et al. 2005, Xia et al. 2006). However, cytokine-cytokine receptor interactions, besides TGF- $\beta 3$, TNF $\alpha$, and their corresponding receptors, IL- $1 \alpha$ 


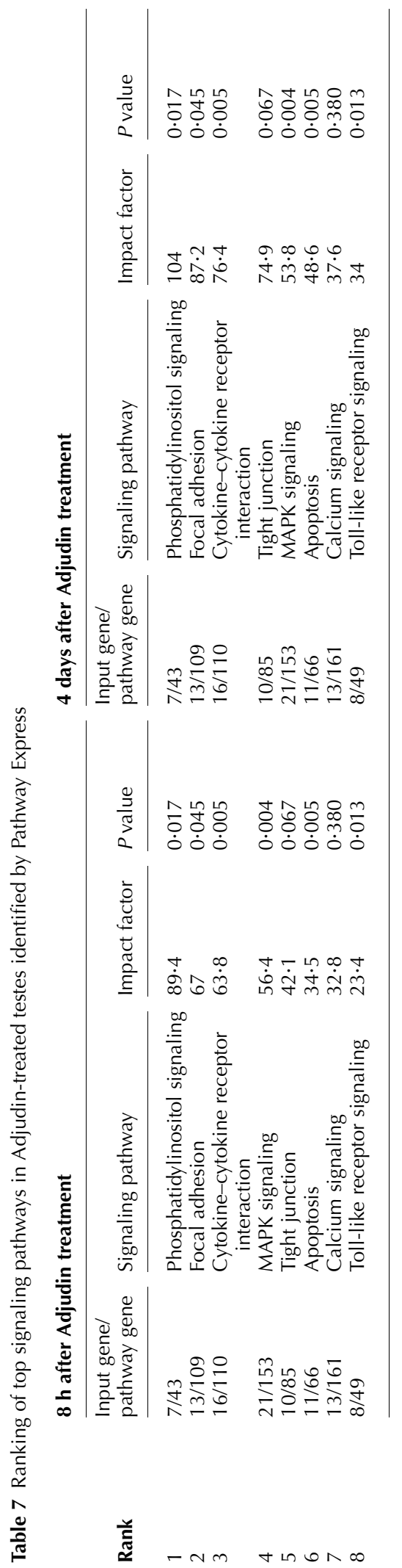

Journal of Endocrinology (2007) 192, 563-583 and its receptors, have been identified to be a crucial mechanism to AJ dynamic regulation. This suggests that an array of cytokines produced by Sertoli and germ cells into the microenvironment at the seminiferous epithelium such as the blood - testis barrior, are working in concert to activate their receptors in tandem to regulate junction restructuring events pertinent to spermatogenesis. Furthermore, the calcium signaling pathway and apoptosis regulatory genes are both activated, which should be carefully evaluated in future studies. Secondly, a set of transcription factors have now been identified, some of which can potentially regulate TJ and/or AJ dynamics, which should be carefully evaluated in future studies. It will also be crucial in future studies to examine if the downstream action of PI-3 kinase, FAK, and MAPK are mediated via one or several of these transcription factors.

\section{Does the Adjudin model reveal physiologically relevant information on the biology of spermatogenesis?}

Besides building expression profiles of thousands of genes in the testis, results from this microarray study could be used to identify genes pertinent to other testicular function. Indeed, many transcripts were found to be significantly induced after multiple rounds offiltering. We did not explore the potential functions of these 'new' genes in this study but they are summarized in Supplementary Table 2 (http://joe.endocrinology-journals. org/content/vol192/issue3/). At present, a number of expression profile studies in the testis are available in the literature (Schlecht et al. 2004, Small et al. 2005, Zhou et al. 2005) pertinent to development, spermatogenesis, and/or fertility regulation. The present study, however, uses an exogenic compound and examines its effect in the testicular gene expression during the time course of germ cell loss with extensive restructuring at the Sertoli-germ cell interface. An important question remains to be addressed: does this drug model reveal the molecular targets pertinent to spermatogenesis?

The approach of using the Adjudin model to identify molecular targets pertinent to junction remodeling during spermatogenesis may be criticized that the changes in the expression of multiple genes are the results of drug toxicity. However, recently completed toxicity studies have shown that the dose used in the present study that was effective to induce germ cell loss had no toxic effects in rats or mice (Cheng et al. 2005, Mruk et al. 2006). Moreover, Adjudin-induced germ cell depletion is reversible (Cheng et al. 2001, Grima et al. 2001). The Adjudin effects on a number of genes seemingly support the notion that this model offers a snapshot of expression alterations that represent their changes during spermatogenesis. For instance, cathepsin L becomes highly expressed at stages VIIVIII (Erikson-Lawrence et al. 1991, Anway et al. 2004), which coincides with spermiation and BTB restructuring, and is also induced during Adjudin-induced germ cell loss from the epithelium, mimicking the cellular events of spermiation. TGF$\beta 3$, which was shown to disrupt both Sertoli-germ cell adhesion and BTB integrity and was known to be stage-specifically 
regulated with the highest expression at stages VI-VIII (Xia \& Cheng 2005, Xia et al. 2006), is also induced after Adjudin treatment at the time of germ cell loss, possibly because of AJ restructuring and this observation is consistent with the results of an earlier report (Xia \& Cheng 2005).

Thus, we hypothesize that the Adjudin-induced restructuring at the Sertoli-germ cell interface mimics the anchoring junction restructuring events in the epithelium during spermatogenesis. This postulate was supported by recent findings that the signaling molecules crucial to Sertoli-germ cell AJ dynamics as identified using the Adjudin model, such as p-FAK, p-c-Src, rMTMR2, and pERK (Li et al. 2000, Siu et al. 2003b, 2005, Xia \& Cheng 2005) have also been found in another in vivo model using androgen/estrogen implants to suppress the intratesticular androgen level which is known to perturb Sertoli-spermatid adhesion in adult testes (O'Donnell et al. 2000, Wong et al. 2005, Xia et al. 2005b, Zhang et al. 2005). This is plausibly due to the fact that there are only a limited number of signaling pathways and molecular mechanisms that control a specific phenotype. For instance, if classified by the types of cell surface receptors involved, the number of signaling pathways in human cells can be as small as 16, and as many as 200 only if counting all the variants of receptors (Fishman \& Porter 2005). Normal spermatogenesis and the Adjudin-induced germ cell depletion model share some phenotypic features, such as junction restructuring, and it is not unusual that they utilize similar signals and/or regulatory mechanisms. This hypothesis should be carefully evaluated in future studies. Likewise, results using Pathway Express to rank the top signaling pathways that were activated by Adjudin in testes also support this postulate. Lipid and protein kinases, such as PI-3 kinase, are important transducers to relay signals from matrix to cells, regulating cytoskeletal remodeling, and cell migration (Carragher \& Frame 2004, Webb et al. 2004). It is not surprising to find that phosphatidylinositol signaling and focal adhesion kinase signaling were the top two pathways. Indeed in studies using the Adjudin model, Sertoli-germ cell co-cultures, and the androgen-suppression model have shown that integrin $\beta 1$, PI-3 kinase, and its downstream protein kinases are crucial regulators of restructuring at the apical ES (Siu et al. 2003b, 2005, Wong et al. 2005). Additionally, MAPKs have also been identified in earlier studies as important regulators of junction dynamics in the testis (Lui et al. 2001, 2003b,c, Wong et al. 2004, Wong \& Yan Cheng 2005, Xia \& Cheng 2005, Xia et al. 2005a, 2006). Taken collectively, these results provide strong evidence that the Adjudin model is useful to study the junction restructuring events pertinent to spermatogenesis.

\section{Molecular signatures for the regulation of junction restructuring during spermatogenesis}

It is of interest to note that junction restructuring and migration of different cell types share similar underlying regulatory mechanisms, since these events are fundamentally conserved across species and cell types regarding the molecules that are involved in these cellular processes. For instance, results from this study have pinpointed the important players in these events in the testis (Tables 3-5). Unsurprisingly, these results were in agreement with other genomic-scale profiling studies which have also identified genes belonging to kinases, proteases, cell adhesion molecules, and cytokine signalings are enriched in migratory cells (Borghese et al. 2006, Wang et al. 2006). We herein discuss target gene groups identified in this Adjudin model, which may be crucial to junction remodeling during germ cell migration.

\section{Cytokines and cytokine receptor signalings}

Besides TGF- $\beta 3$ (Xia \& Cheng 2005), Adjudin indeed activated the expression of several cytokines and chemokines in adult rat testes. ILs and chemokines are typically involved in inflammatory responses and they are also crucial to T-cell migration (Petersen et al. 2006). Other studies have shown that cytokines are important players of immunological responses in the testis after stress or injury (Hedger \& Meinhardt 2003). However, as no macrophage infiltration in the testis was observed after Adjudin treatment, it is logical to conclude that the inflammation response to Adjudin is probably a negligible possibility. The activation of multiple cytokines and chemokines at the time of germ cell loss implies that these paracrine/autocrine factors are involved in the signaling cascades that lead to the restructuring at the Sertoligerm cell interface. For instance, IL- $1 \alpha$ is a pro-inflammatory cytokine but in the testis it is also secreted by Sertoli cells in the absence of local inflammation (Sultana et al. 2004). An IL-1 $\alpha$ isoform was found to be secreted bidirectionally to the interstitium and intratubular compartment (Sultana et al. 2004). As a paracrine factor, it regulates Leydig cell steroidogenesis with age-dependent effects (Sultana et al. 2004). By 8 h after Adjudin treatment, a drastic induction $(8 \cdot 6$-fold) of IL- $1 \alpha$ was detected, which strongly suggests that its early response signifies its significance in AJ restructuring, which should be investigated in future studies.

Cx3cl1 (or fractalkine) is also expressed in Leydig cells, Sertoli cells, and spermatogonia and it is believed to be regulating cell-cell interactions in and out of the seminiferous tubules and other epithelia (Rossi et al. 1998, Habasque et al. 2003). In the Adjudin model, a 3·2- and 5·3-fold increase in expression at $8 \mathrm{~h}$ and at day 4 respectively, were detected. Vgf (VGF nerve growth factor inducible) was found to be highly induced after Adjudin treatment (3- and 16-fold increase at $8 \mathrm{~h}$ and at day 4 respectively), although its basal expression level in the rat testis was relatively low (raw signal intensity at $\sim 30$ ). There is no literature on Vgf in the testis, since Vgf is a neuronsecreted polypeptide, particularly abundant in adult hypothalamus. $V g f^{-}$mice were found to be small, hypermetabolic, hyperactive, and infertile for both males and females (Hahm et al. 1999), which is likely the result of a reduced production of pituitary gonadotropin hormones (Hahm et al. 1999), which in turn, affected spermatogenesis in the testis. In short, these cytokines should be examined 
closely to determine if they play any role in Sertoli-germ cell AJ restructuring during spermatogenesis.

\section{Proteases and protease inhibitors}

Cathepsin L and tissue-type plasminogen activator (tPA) are known to be expressed stage specifically in the testis (Vihko et al. 1989, Chung et al. 1998). Cathepsin L and urokinase-type plasminogen activator (uPA) are also induced in the cadmium model (Wong et al. 2004), supporting the notion that they take part in the regulation of junction restructuring. Similarly, tissue inhibitor of metalloproteases 1 (TIMP-1) was also found to regulate BTB and AJ dynamics (Mruk et al. 2003, Siu et al. $2003 a$ ), but its activation in the Adjudin model has not been reported until now (see Table 4). The function of other proteases and protease inhibitors, such as Prss11 and Serping1, in these events are not known. For instance, no reports are found in the literature regarding the expression of Spin $2 c$ or Serping 1 by the testis, but they are highly induced after Adjudin treatment (Table 4). It will be of interest to examine the regulation of these proteins in the testis during the epithelial cycle and their role in $\mathrm{AJ}$ restructuring.

\section{Transcription factors}

Transcription factors that were induced by Adjudin in the testis were summarized in Table 6. For example, early growth responses 1 and 2 (Egr 1 and Egr2) were greatly induced $8 \mathrm{~h}$ after Adjudin treatment (Table 3). They belong to the Egr family of zinc-finger transcription factors, which are known to be involved in cellular growth and differentiation (Hofmann et al. 2005, Oatley et al. 2006). Another gene in the same family, Egr4 is also essential for spermatogenesis. Male Egr4 null mice were infertile because most of the germ cells underwent apoptosis at the early-mid pachytene spermatocyte stage (Tourtellotte et al. 1999). The involvement of these transcription factors in junction restructuring in the testis should be closely examined in future studies.

\section{Signaling molecules}

A large number of signaling molecules were found to be induced after Adjudin treatment. Although it is still difficult to put them in context with the regulation of cellular events at the Sertoli-germ cell interface, these findings, nonetheless, have provided new leads for future research. For example, Crim 1 (cysteine-rich motor neuron 1) was found to be activated by $2 \cdot 3$-fold at $8 \mathrm{~h}$ and $5 \cdot 9$-fold at day 4 (Table 5 ). Crim 1 was originally identified in the developing nervous systems in vertebrates (Kolle et al. 2000). This protein was activated during murine gonad development and expressed strongly in Sertoli cells (Georgas et al. 2000). It functions to antagonize bone morphogenic proteins, and possibly TGF- $\beta$ s (Georgas et al. 2000). It is not known if adult testes also express Crim 1 but the signal intensity of Crim 1 detected by microarray was comparable with that of TGF- $\beta 3$ in control testes (175 vs 135), indicating Crim1 indeed is expressed in adult testes. Since TGF- $\beta$ superfamily genes play essential roles in testicular development and function (Skinner 1993, Gnessi et al. 1997, Shimasaki et al. 2004, Xia et al. 2005a), the identification of a new regulator of this superfamily is of great interest in future studies to examine their interacting physiological roles in maintaining spermatogenesis and testicular function.

\section{Summary and conclusion}

This microarray profiling study has identified different target genes belonging to several functional groups that may be important for the regulation of junction restructuring during spermatogenesis. Some of these genes highlighted herein merit additional research to delineate their role and involvement in spermatogenesis.

\section{Acknowledgements}

The authors thank Wenxiang Zhang and Dr Xuning Wang at The Rockefeller University Genomics Resource Center (New york, NY, USA) for their excellent technical assistance in the microarray experiments and data analysis. The authors declare that there is no conflict of interest that would prejudice the impartiality of this scientific work.

\section{Funding}

Supported in part by grants from the National Institutes of Health (NICHD, U01 HD045908 and U54 HD029990, Project 3 to C Y C), the CONRAD Program (CICCR, CIG 01-72 to CYC; CIG 01-74 to DDM) and Hong Kong Research Grant Council (HKU 7413/04M and HKU $7536 / 05 \mathrm{M}$ to WML). WX was the recipient of a University of Hong Kong Postgraduate Research Studentship Award.

\section{References}

Alcivar AA, Hake LE, Hardy MP \& Hecht NB 1990 Increased levels of junB and c-jun mRNAs in male germ cells following testicular cell dissociation. Maximal stimulation in prepuberal animals. Journal of Biological Chemistry 265 20160-20165.

Anway MD, Wright WW, Zirkin BR, Korah N, Mort JS \& Hermo L 2004 Expression and localization of cathepsin $\mathrm{K}$ in adult rat Sertoli cells. Biology of Reproduction 70 562-569.

Bakel Hv \& Holstege FCP 2004 In control: systematic assessment of microarray performance. EMBO Reports 5 964-969.

Borghese L, Fletcher G, Mathieu J, Atzberger A, Eades WC, Cagan RL \& Rorth P 2006 Systematic analysis of the transcriptional switch inducing migration of border cells. Developmental Cell 10 497-508.

Carragher NO \& Frame MC 2004 Focal adhesion and actin dynamics: a place where kinases and proteases meet to promote invasion. Trends in Cell Biology 14 241-249. 
Chen YM, Lee NPY, Mruk DD, Lee WM \& Cheng CY 2003 Fer kinase/FerT and adherens junction dynamics in the testis: an in vitro and in vivo study. Biology of Reproduction 69 656-672.

Cheng CY \& Bardin CW 1987 Identification of two testosterone-responsive testicular proteins in Sertoli cell-enriched culture medium whose secretion is suppressed by cells of the intact seminiferous tubule. Journal of Biological Chemistry 262 12768-12779.

Cheng CY \& Mruk DD 2002 Cell junction dynamics in the testis: sertoligerm cell interactions and male contraceptive development. Physiological Reviews 82 825-874.

Cheng CY, Grima J, Stahler MS, Guglielmotti A, Silvestrini B \& Bardin CW 1990 Sertoli cell synthesizes and secretes a protease inhibitor, a2macroglobulin. Biochemistry 29 1063-1068.

Cheng CY, Silvestrini B, Grima J, Mo M-Y, Zhu L-J, Jahansson E, Saso L, Leone M-G, Palmery M \& Mruk D 2001 Two new male contraceptives exert their effects by depleting germ cells prematurely from the testis. Biology of Reproduction 65 449-461.

Cheng CY, Mruk D, Silvestrini B, Bonanomi M, Wong C-H, Siu MKY, Lee NPY, Lui W-Y \& Mo M-Y 2005 AF-2364 [1-(2,4-dichlorobenzyl)$1 \mathrm{H}$-indazole-3-carbohydrazide] is a potential male contraceptive: a review of recent data. Contraception 72 251-261.

Chung SSW, Zhu L-J, Mo M-Y, Silvestrini B, Lee WM \& Cheng CY 1998 Evidence for cross-talk between Sertoli and germ cells using selected cathepsins as markers. Journal of Andrology 19 686-703.

Davis AC, Wims M, Spotts GD, Hann SR \& Bradley A 1993 A null c-myc mutation causes lethality before 10.5 days of gestation in homozygotes and reduced fertility in heterozygous female mice. Genes and Development 7 671-682.

de Kretser DM \& Kerr JB 1994 The cytology of the testis. In The Physiology of Reproduction, 2 , pp 1177-1300. Eds E Knobil \& JD Neill. New York: Raven Press.

Draghici S, Khatri P, Bhavsar P, Shah A, Krawetz SA \& Tainsky MA 2003a Onto-Tools, the toolkit of the modern biologist: Onto-Express, OntoCompare, Onto-Design and Onto-Translate. Nucleic Acids Research 31 3775-3781.

Draghici S, Khatri P, Martins RP, Ostermeier GC \& Krawetz SA $2003 b$ Global functional profiling of gene expression. Genomics 81 98-104.

Eddy EM 1998 Regulation of gene expression during spermatogenesis. Seminars in Cell and Developmental Biology 9 451-457.

Erikson-Lawrence M, Zabludoff SD \& Wright WW 1991 Cyclic protein-2, a secretory product of rat Sertoli cells, is the proenzyme form of cathepsin L. Molecular Endocrinology 5 1789-1798.

Fishman MC \& Porter JA 2005 A new grammar for drug discovery. Nature 437 491-493.

Garcia-Cao I, Lafuente MJ, Criado LM, Diaz-Meco MT, Serrano M \& Moscat J 2003 Genetic inactivation of Par4 results in hyperactivation of NF$\kappa \mathrm{B}$ and impairment of JNK and $\mathrm{p} 38$. EMBO Reports 4 307-312.

Garcia-Montero AC, Vasseur S, Giono LE, Canepa E, Moreno S, Dagorn JC \& Iovanna JL 2001 Transforming growth factor $\beta-1$ enhances Smad transcriptional activity through activation of $\mathrm{p} 8$ gene expression. Biochemical Journal 357 249-253.

Georgas K, Bowles J, Yamada T, Koopman P \& Little MH 2000 Characterisation of Crim1 expression in the developing mouse urogenital tract reveals a sexually dimorphic gonadal expression pattern. Developmental Dynamics 219 582-587.

Gnessi L, Fabbri A \& Spera G 1997 Gonadal peptides as mediators of development and functional control of the testis: an integrated system with hormones and local environment. Endocrine Reviews 18 541-609.

Goswami A, Ranganathan P \& Rangnekar VM 2006 The phosphoinositide 3-kinase/Akt1/Par-4 axis: a cancer-selective therapeutic target. Cancer Research 66 2889-2892.

Grima J, Zhu L-j \& Cheng CY 1997 Testin Is tightly associated with testicular cell membrane upon its secretion by Sertoli cells whose steady-state mRNA level in the testis correlates with the turnover and integrity of inter-testicular cell junctions. Journal of Biological Chemistry 272 6499-6509.
Grima J, Silvestrini B \& Cheng CY 2001 Reversible inhibition of spermatogenesis in rats using a new male contraceptive, 1-(2,4dichlorobenzyl)-indazole-3-carbohydrazide. Biology of Reproduction 64 $1500-1508$.

Habasque C, Satie A-P, Aubry F, Jegou B \& Samson M 2003 Expression of fractalkine in the rat testis: molecular cloning of a novel alternative transcript of its gene that is differentially regulated by pro-inflammatory cytokines. Molecular Human Reproduction 9 449-455.

Hahm S, Mizuno TM, Wu TJ, Wisor JP, Priest CA, Kozak CA, Boozer CN, Peng B, McEvoy RC, Good P et al. 1999 Targeted deletion of the Vof gene indicates that the encoded secretory peptide precursor plays a novel role in the regulation of energy balance. Neuron 23 537-548.

Hai T \& Hartman MG 2001 The molecular biology and nomenclature of the activating transcription factor/cAMP responsive element binding family of transcription factors: activating transcription factor proteins and homeostasis. Gene 273 1-11.

Hartman MG, Lu D, Kim M-L, Kociba GJ, Shukri T, Buteau J, Wang X, Frankel WL, Guttridge D, Prentki M et al. 2004 Role for activating transcription factor 3 in stress-induced $\beta$-cell apoptosis. Molecular and Cellular Biology 24 5721-5732.

Hedger MP \& Meinhardt A 2003 Cytokines and the immune-testicular axis. Journal of Reproductive Immunology 58 1-26.

Hofmann M-C, Braydich-Stolle L \& Dym M 2005 Isolation of male germline stem cells; influence of GDNF. Developmental Biology 279 114-124.

Jenab S \& Morris PL 1997 Transcriptional regulation of Sertoli cell immediate early genes by interleukin- 6 and interferon- $\gamma$ is mediated through phosphorylation of STAT-3 and STAT-1 proteins. Endocrinology 138 2740-2746.

Johnson RS, Spiegelman BM \& Papaioannou V 1992 Pleiotropic effects of a null mutation in the c-fos proto-oncogene. Cell 71 577-586.

Johnson RS, van Lingen B, Papaioannou VE \& Spiegelman BM 1993 A null mutation at the c-jun locus causes embryonic lethality and retarded cell growth in culture. Genes and Development 7 1309-1317.

Khatri P, Bhavsar P, Bawa G \& Draghici S 2004 Onto-Tools: an ensemble of web-accessible, ontology-based tools for the functional design and interpretation of high-throughput gene expression experiments. Nucleic Acids Research 32 W449-W456.

Khatri P, Sellamuthu S, Malhotra P, Amin K, Done A \& Draghici S 2005 Recent additions and improvements to the Onto-Tools. Nucleic Acids Research 33 W762-W765.

Koji T, Izumi S, Tanno M, Moriuchi T \& Nakane PK 1988 Localization in situ of c-myc mRNA and c-myc protein in adult mouse testis. Histochemical Journal 20 551-557.

Kolle G, Georgas K, Holmes GP, Little MH \& Yamada T 2000 CRIM1, a novel gene encoding a cysteine-rich repeat protein, is developmentally regulated and implicated in vertebrate CNS development and organogenesis. Mechanisms of Development 90 181-193.

Lafuente MJ, Martin P, Garcia-Cao I, Diaz-Meco MT, Serrano M \& Moscat J 2003 Regulation of mature T lymphocyte proliferation and differentiation by Par-4. EMBO Journal 22 4689-4698.

Lau ASN \& Mruk DD 2003 Rab8B GTPase and junction dynamics in the testis. Endocrinology 144 1549-1563.

Lee NPY \& Cheng CY 2005 Protein kinases and adherens junction dynamics in the seminiferous epithelium of the rat testis. Journal of Cellular Physiology $202344-360$

Lee NPY, Mruk D, Lee WM \& Cheng CY 2003 Is the cadherin/catenin complex a functional unit of cell-cell actin-based adherens junctions in the rat testis? Biology of Reproduction 68 489-508.

Lee NPY, Mruk DD, Conway AM \& Cheng CY 2004 Zyxin, axin, and Wiskott-Aldrich syndrome protein are adaptors that link the cadherin/ catenin protein complex to the cytoskeleton at adherens junctions in the seminiferous epithelium of the rat testis. Journal of Andrology 25 200-215.

Lee NPY, Mruk DD, Wong C-H \& Cheng CY 2005 Regulation of Sertoligerm cell adherens junction dynamics in the testis via the nitric oxide synthase (NOS)/cGMP/protein kinase G (PRKG)/ $\beta$-catenin (CATNB) signaling pathway: an in vitro and in vivo study. Biology of Reproduction $\mathbf{7 3}$ 458-471. 
Lee WM, Cheng CY, Bardin CW, Gunsalsu GL \& Musto NA 1986 Measurement of a follicle-stimulating hormone-responsive protein of Sertoli cell origin using an enzyme-linked immunoblot assay. Endocrinology 119 1914-1921.

Lee SL, Sadovsky Y, Swirnoff AH, Polish JA, Goda P, Gavrilina G \& Milbrandt J 1996 Luteinizing hormone deficiency and female infertility in mice lacking the transcription factor NGFI-A (Egr-1). Science 273 1219-1221.

Li JCH, Samy ET, Grima J, Chung SSW, Mruk D, Lee WM, Silvestrini B \& Cheng CY 2000 Rat testicular myotubularin, a protein tyrosine phosphatase expressed by Sertoli and germ cells, is a potenial marker for studying cell-cell interactions in the rat testis. Journal of Cellular Physiology 185 366-385.

Lim K \& Hwang B-D 1995 Follicle-stimulating hormone transiently induces expression of protooncogene c-myc in primary Sertoli cell cultures of early pubertal and prepubertal rat. Molecular and Cellular Endocrinology 111 51-56.

Lim K, Yoo JH, Kim KY, Kweon GR, Kwak ST \& Hwang BD 1994 Testosterone regulation of proto-oncogene c-myc expression in primary Sertoli cell cultures from prepubertal rats. Journal of Andrology 15 543-550.

Lui WY, Lee WM \& Cheng CY 2001 Transforming growth factor- $\beta 3$ perturbs the inter-Sertoli tight junction permeability barrier in vitro possibly mediated via its effects on occludin, zonula occludens-1, and claudin- 11 . Endocrinology 142 1865-1877.

Lui WY, Lee WM \& Cheng CY 2003a Sertoli-germ cell adherens junction dynamics in the testis are regulated by RhoB GTPase via the ROCK/LIMK signaling pathway. Biology of Reproduction 68 2189-2206.

Lui WY, Lee WM \& Cheng CY $2003 b$ Transforming growth factor- $\beta 3$ regulates the dynamics of Sertoli cell tight junctions via the p38 mitogenactivated protein kinase pathway. Biology of Reproduction 68 1597-1612.

Lui WY, Wong C-H, Mruk DD \& Cheng CY 2003c TGF- $\beta 3$ regulates the blood-testis barrier dynamics via the p38 mitogen activated protein (MAP) kinase pathway: an in vivo study. Endocrinology 144 1139-1142.

Mallo GV, Fiedler F, Calvo EL, Ortiz EM, Vasseur S, Keim V, Morisset J \& Iovanna JL 1997 Cloning and expression of the rat p8 cDNA, a new gene activated in pancreas during the acute phase of pancreatitis, pancreatic development, and regeneration, and which promotes cellular growth. Journal of Biological Chemistry 272 32360-32369.

Matsuyama T, Kimura T, Kitagawa M, Pfeffer K, Kawakami T, Watanabe N, Kundig TM, Amakawa R, Kishihara K \& Wakeham A 1993 Targeted disruption of IRF-1 or IRF-2 results in abnormal type I IFN gene induction and aberrant lymphocyte development. Cell 75 83-97.

Matzuk MM 2004 Germ-line immortality. PNAS 101 16395-16396.

McLean DJ, Johnston DS, Russell LD \& Griswold MD 2001 Germ cell transplantation and the study of testicular function. Trends in Endocrinology and Metabolism 12 16-21.

Milde-Langosch K 2005 The Fos family of transcription factors and their role in tumourigenesis. European Journal of Cancer 41 2449-2461.

Mruk DD \& Cheng CY 2004a Cell-cell interactions at the ectoplasmic specialization in the testis. Trends in Endocrinology and Metabolism 15 439-447.

Mruk DD \& Cheng CY $2004 b$ Sertoli-Sertoli and Sertoli-germ cell interactions and their significance in germ cell movement in the seminiferous epithelium during spermatogenesis. Endocrine Reviews 25 747-806.

Mruk DD, Siu MKY, Conway AM, Lee NPY, Lau ASN \& Cheng CY 2003 Role of tissue inhibitor of metalloproteases- 1 in junction dynamics in the testis. Journal of Andrology 24 510-523.

Mruk DD, Wong C-H, Silvestrini B \& Cheng CY 2006 A novel male contraceptive specifically targeting germ cell adhesion. Nature Medicine $\mathbf{1 2}$ 1323-1328.

O’Donnell L, Stanton PG, Bartles JR \& Robertson DM 2000 Sertoli cell ectoplasmic specializations in the seminiferous epithelium of the testosterone-suppressed adult rat. Biology of Reproduction 63 99-108.

O’Donovan KJ, Tourtellotte WG, Millbrandt J \& Baraban JM 1999 The EGR family of transcription-regulatory factors: progress at the interface of molecular and systems neuroscience. Trends in Neuroscience 22 167-173.

Oatley JM, Avarbock MR, Telaranta AI, Fearon DT \& Brinster RL 2006 Identifying genes important for spermatogonial stem cell self-renewal and survival. PNAS 103 9524-9529.
Papadopoulos V \& Dym M 1994 Sertoli cell differentiation on basement membrane is mediated by the c-fos protooncogene. PNAS 91 7027-7031.

Parvinen M 1982 Regulation of the seminiferous epithelium. Endocrine Reviews 3 404-417.

Petersen SL, Krishnan S \& Hudgens ED 2006 The aryl hydrocarbon receptor pathway and sexual differentiation of neuroendocrine functions. Endocrinology 147 s33-s42.

Rossi DL, Hardiman G, Copeland NG, Gilbert DJ, Jenkins N, Zlotnik A \& Bazan JF 1998 Cloning and characterization of a new type of mouse chemokine. Genomics 47 163-170.

Russell LD 1977 Movement of spermatocytes from the basal to the adluminal compartment of the rat testis. American Journal of Anatomy 148 313-328.

Sato M, Taniguchi T \& Tanaka N 2001 The interferon system and interferon regulatory factor transcription factors - studies from gene knockout mice. Cytokine and Growth Factor Reviews 12 133-142.

Schlecht U, Demougin P, Koch R, Hermida L, Wiederkehr C, Descombes P, Pineau C, Jegou B \& Primig M 2004 Expression profiling of mammalian male meiosis and gametogenesis identifies novel candidate genes for roles in the regulation of fertility. Moloecular Biology of the Cell 15 1031-1043.

Schneider-Maunoury S, Topilko P, Seitanidou T, Levi G, Cohen-Tannoudji M, Pournin S, Babinet C \& Charnay P 1993 Disruption of Krox-20 results in alteration of rhombomeres 3 and 5 in the developing hindbrain. Cell $\mathbf{7 5}$ 1199-1214.

Schultz R, Penttila TL, Parvinen M, Persson H, Hokfelt T \& Pelto-Huikko M 1995 Expression of immediate early genes in tubular cells of rat testis. Biology of Reproduction 52 1215-1226.

Shimasaki S, Moore RK, Otsuka F \& Erickson GF 2004 The bone morphogenetic protein system in mammalian reproduction. Endocrine Reviews 25 72-101.

Siu MKY \& Cheng CY 2004 Interactions of proteases, protease inhibitors, and the $\beta 1$ integrin/laminin $\gamma 3$ protein complex in the regulation of ectoplasmic specialization dynamics in the rat testis. Biology of Reproduction 70 945-964.

Siu MKY, Lee WM \& Cheng CY 2003a The interplay of collagen IV, tumor necrosis factor- $\alpha$, gelatinase B (matrix metalloprotease-9), and tissue inhibitor of metalloproteases-1 in the basal lamina regulates Sertoli celltight junction dynamics in the rat testis. Endocrinology 144 371-387.

Siu MKY, Mruk DD, Lee WM \& Cheng CY 2003b Adhering junction dynamics in the testis are regulated by an interplay of $\beta 1$-integrin and the focal adhesion complex-associated proteins. Endocrinology 144 2141-2163.

Siu MKY, Wong C-H, Lee WM \& Cheng CY 2005 Sertoli-germ cell anchoring junction dynamics in the testis are regulated by an interplay of lipid and protein kinases. Journal of Biological Chemistry $28025029-25047$.

Skinner MK 1993 Secretion of growth factors and other regulatory factors. In The Sertoli Cell, pp 238-247. Eds LD Russell \& MD Griswold. Clearwater, FL: Cache River.

Small CL, Shima JE, Uzumcu M, Skinner MK \& Griswold MD 2005 Profiling gene expression during the differentiation and development of the murine embryonic gonad. Biology of Reproduction 72 492-501.

Stoughton RB 2005 Applications of DNA microarrays in biology. Annual Review of Biochemistry 74 53-82.

Sultana T, Svechnikov KV, Gustafsson K, Wahlgren A, Tham E, Weber G \& Söder O 2004 Molecular identity, expression and functional analysis of interleukin$1 \alpha$ and its isoforms in rat testis. Asian Journal of Andrology 6 149-153.

Sun H, Lu B, Li R-Q, Flavell RA \& Taneja R 2001 Defective T cell activation and autoimmune disorder in Stra13-deficient mice. Nature Immunology 2 1040-1047.

Sushma Gurumurthy VMR 2004 Par-4 inducible apoptosis in prostate cancer cells. Journal of Cellular Biochemistry 91 504-512.

Swiatek PJ \& Gridley T 1993 Perinatal lethality and defects in hindbrain development in mice homozygous for a targeted mutation of the zinc finger gene Krox20. Genes and Development 7 2071-2084.

Takeda K \& Akira S 2000 STAT family of transcription factors in cytokinemediated biological responses. Cytokine and Growth Factor Reviews 11 199-207.

Takeda K, Noguchi K, Shi W, Tanaka T, Matsumoto M, Yoshida N, Kishimoto T \& Akira S 1997 Targeted disruption of the mouse Stat3 gene leads to early embryonic lethality. PNAS 94 3801-3804. 
Tanaka N \& Taniguchi T 2000 The interferon regulatory factors and oncogenesis. Seminars in Cancer Biology 10 73-81.

Topilko P, Schneider-Maunoury S, Levi G, Trembleau A, Gourdji D, Driancourt M-A, Rao CV \& Charnay P 1998 Multiple pituitary and ovarian defects in Krox-24 (NGFI-A. Egr-1)-targeted mice. Molecular Endocrinology 12 107-122.

Tourtellotte WG, Nagarajan R, Auyeung A, Mueller C \& Milbrandt J 1999 Infertility associated with incomplete spermatogenic arrest and oligozoospermia in Egr4-deficient mice. Development 126 5061-5071.

Vasseur S, Hoffmeister A, Garcia-Montero A, Barthet M, Saint-Michel L, Berthezene P, Fiedler F, Closa D, Dagorn J \& Iovanna J 2003 Mice with targeted disruption of $\mathrm{p} 8$ gene show increased sensitivity to lipopolysaccharide and DNA microarray analysis of livers reveals an aberrant gene expression response. BMC Gastroenterology 3 25-34.

Vihko KK, Penttila TL, Parvinen M \& Belin D 1989 Regulation of urokinaseand tissue-type plasminogen activator gene expression in the rat seminiferous epithelium. Molecular Endocrinology 3 52-59.

Wang X, Bo J, Bridges T, Dugan KD, Pan T-C, Chodosh LA \& Montell DJ 2006 Analysis of cell migration using whole-genome expression profiling of migratory cells in the Drosophila ovary. Developmental Cell 10 483-495.

Webb DJ, Donais K, Whitmore LA, Thomas SM, Turner CE, Parsons JT \& Horwitz AF 2004 FAK-Src signalling through paxillin, ERK and MLCK regulates adhesion disassembly. Nature Cell Biology 6 154-161.

Wong C-H \& Yan Cheng C 2005 Mitogen-activated protein kinases, adherens junction dynamics, and spermatogenesis: A review of recent data. Developmental Biology 286 1-15.

Wong C-H, Mruk DD, Lui WY \& Cheng CY 2004 Regulation of bloodtestis barrier dynamics: an in vivo study. Journal of Cell Science 117 783-798.

Wong C-H, Xia W, Lee NPY, Mruk DD, Lee WM \& Cheng CY 2005 Regulation of ectoplasmic specialization dynamics in the seminiferous epithelium by focal adhesion-associated proteins in testosterone-suppressed rat testes. Endocrinology 146 1192-1204.

Xia W \& Cheng CY 2005 TGF- $\beta 3$ regulates anchoring junction dynamics in the seminiferous epithelium of the rat testis via the Ras/ERK signaling pathway: an in vivo study. Developmental Biology 280 321-343.
Xia W, Mruk DD, Lee WM \& Cheng CY 2005a Cytokines and junction restructuring during spermatogenesis - a lesson to learn from the testis. Cytokine and Growth Factor Reviews 16 469-493.

Xia W, Wong C-H, Lee NPY, Lee WM \& Cheng CY $2005 b$ Disruption of Sertoli-germ cell adhesion function in the seminiferous epithelium of the rat testis can be limited to adherens junctions without affecting the bloodtestis barrier integrity: an in vivo study using an androgen suppression model. Journal of Cellular Physiology 205 141-157.

Xia W, Mruk DD, Lee WM \& Cheng CY 2006 Differential interactions between TGF- $\beta 3 / \mathrm{T} \beta \mathrm{R} 1$, TAB1 and CD2AP disrupt blood-testis barrier and Sertoli-germ cell adhesion. Journal of Biological Chemistry 28116799 16813.

Yan HHN \& Cheng CY 2005 Blood-testis barrier dynamics are regulated by an engagement/disengagement mechanism between tight and adherens junctions via peripheral adaptors. PNAS 102 11722-11727.

Zawel L, Yu J, Torrance CJ, Markowitz S, Kinzler KW, Vogelstein B \& Zhou S 2002 DEC1 is a downstream target of TGF- $\beta$ with sequence-specific transcriptional repressor activities. PNAS 99 2848-2853.

Zhang J, Wong CH, Xia W, Mruk DD, Lee NPY, Lee WM \& Cheng CY 2005 Regulation of Sertoli-germ cell adherens junction dynamics via changes in protein-protein interactions of the $\mathrm{N}$-cadherin- $\beta$ catenin protein complex which are possibly mediated by $\mathrm{c}-\mathrm{Src}$ and MTMR2: an in vivo study using an androgen suppression model. Endocrinology 146 1268-1284.

Zhou Q, Shima JE, Nie R, Friel PJ \& Griswold MD 2005 Androgenregulated transcripts in the neonatal mouse testis as determined through microarray analysis. Biology of Reproduction 72 1010-1019.

\section{Received in final form 12 December 2006 \\ Accepted 22 December 2006 \\ Made available online as an Accepted Preprint \\ 28 December 2006}

